\title{
CORPORATE GOVERNANCE ISSUES SURROUNDING EXECUTIVE COMPENSATION AND EXECUTIVE SEVERANCE
}

\author{
Andrea W. Zanetti \\ Master of Business Administration \\ Ryerson University, 2009
}

\begin{abstract}
This paper seeks to explain why and how executive severances of publicly-traded Canadian and U.S. companies have reached the financial levels they have, generating public and shareholder outrage and causing governments on both sides of the border to introduce new legislation.
\end{abstract}

The paper investigates the role of the CEO, boards and shareholders in the setting of executive compensation. As the origins of the three roles lie in business corporation law, the legislative framework of Canadian and U.S. companies is presented to permit the reader to understand the legal accountabilities and rights of each of the three parties.

The paper identifies that executives may exercise substantial influence over boards, possibly impeding effective governance. The paper concludes that effective governance, including greater board independence and board competence in executive compensation matters will help to improve board functioning and minimize the effects of the agency problem, cronyism and managerial power. 


\section{Acknowledgements}

I would like to thank Dr. Avner Levin for his support in helping me produce this thesis. His input helped me develop a strong paper that covered the many aspects of this challenging topic.

Thank you also to Dr. Nina Cole for providing additional feedback. 


\section{Contents}

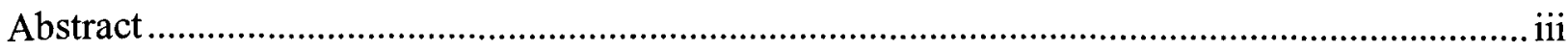

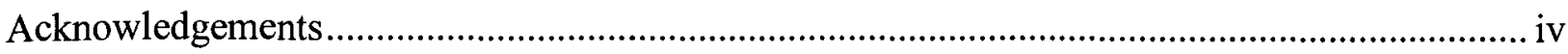

Contents

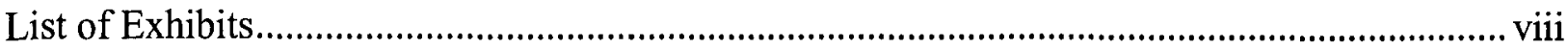

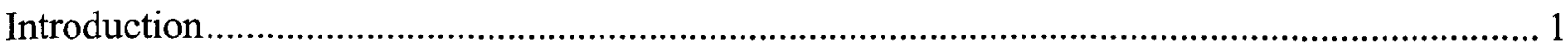

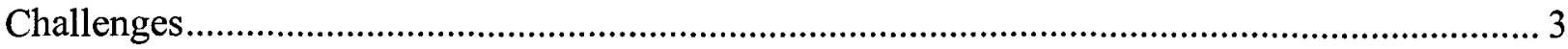

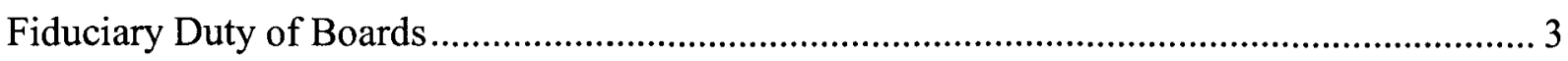

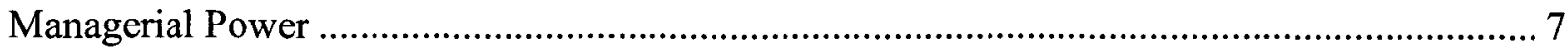

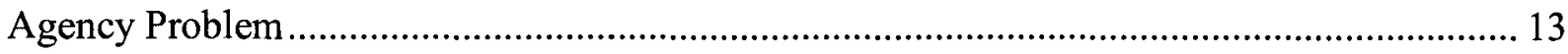

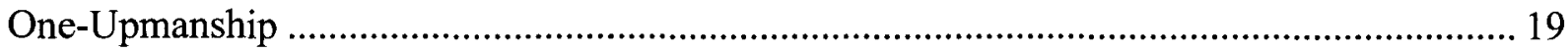

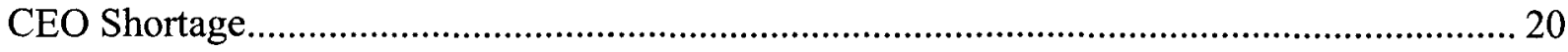

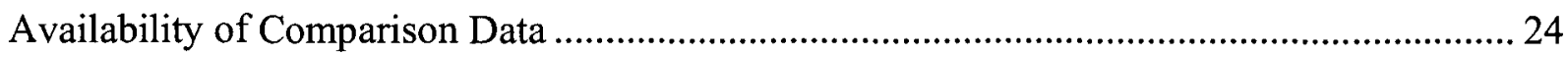

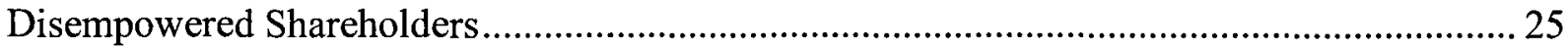

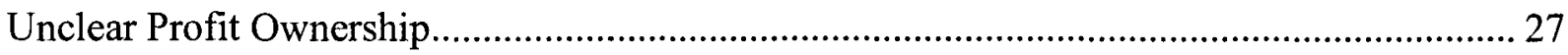

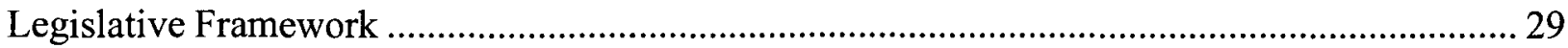

Canada: Overview of Publicly Traded Companies and the Role of Directors............................ 29

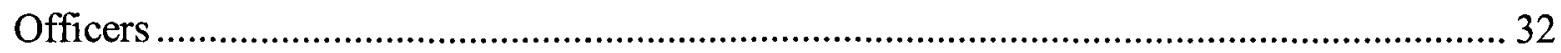

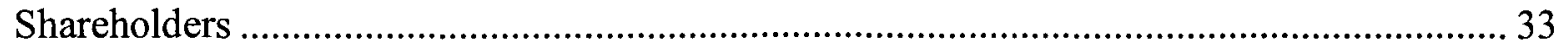

United States: Overview of Publicly Traded Companies and the Role of Directors ................. 34

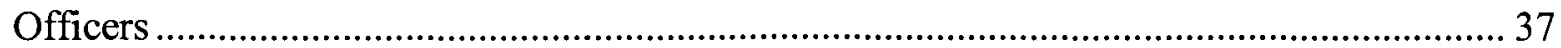

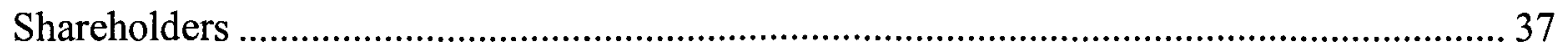

Comments regarding Canadian and U.S. Corporate Law ............................................................ 39

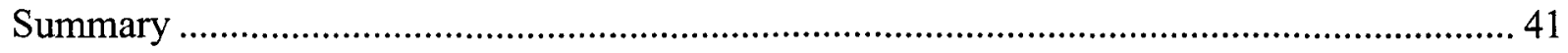


Growth of CEO Base Salaries and Severances.

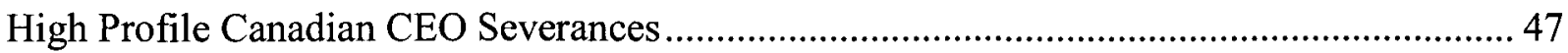

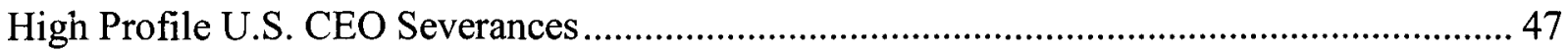

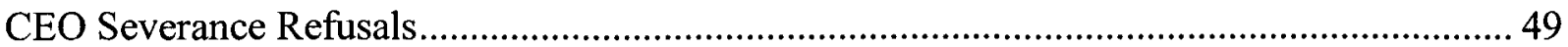

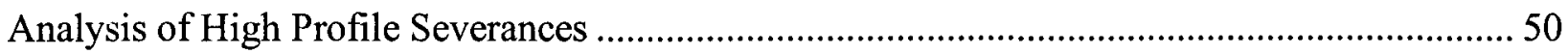

Situations Requiring Payment of Severance ………................................................................ 50

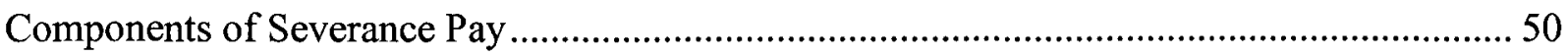

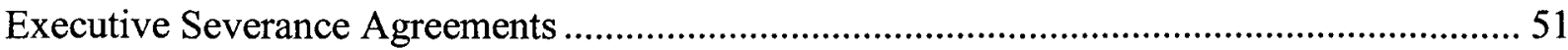

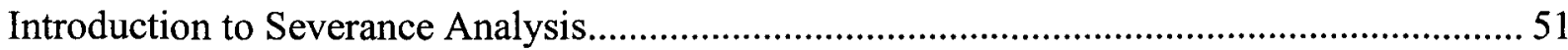

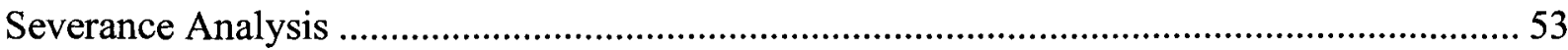

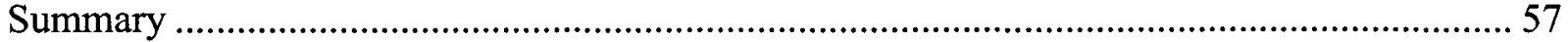

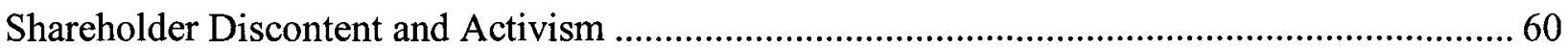

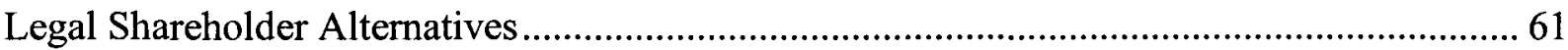

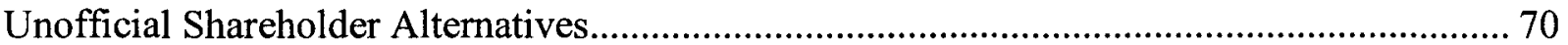

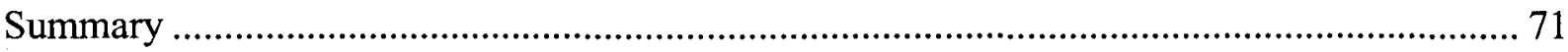

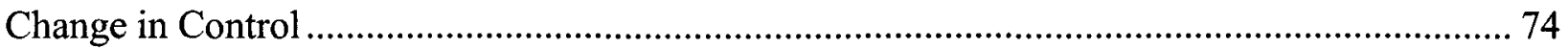

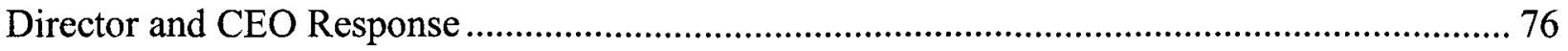

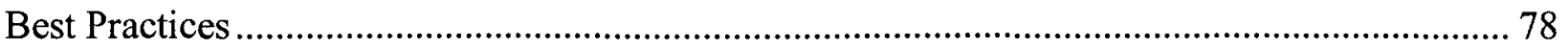

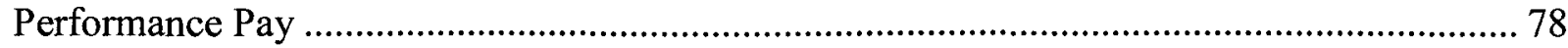

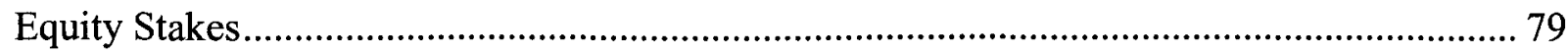

Termination Pay, including Change in Control Provisions.......................................................... 80

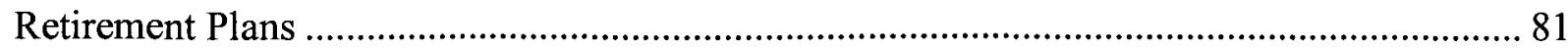

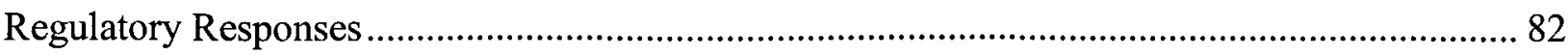

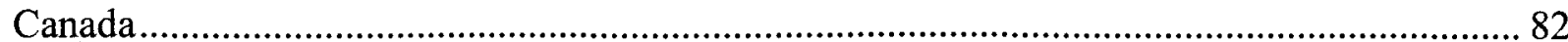




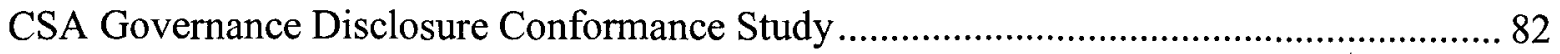

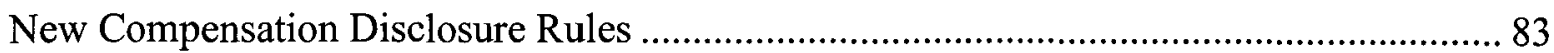

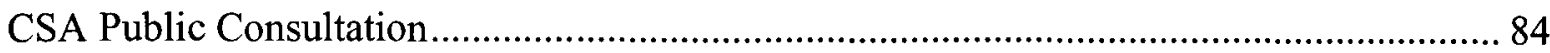

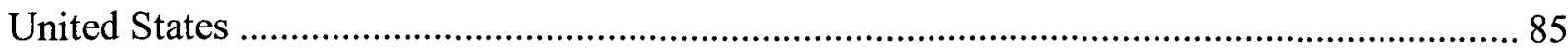

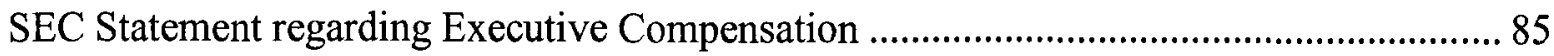

U.S. Department of Treasury Statement regarding Executive Compensation ....................... 85

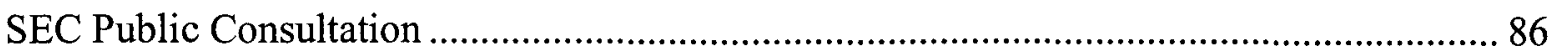

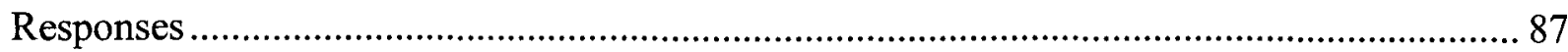

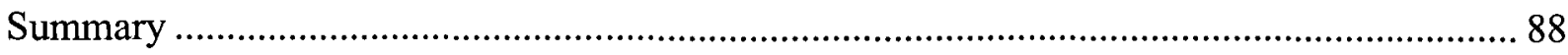

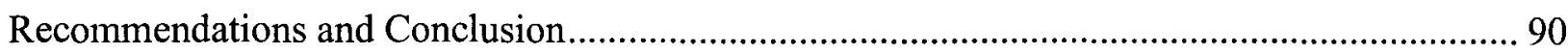

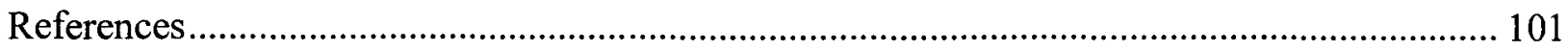




\section{List of Exhibits}

Exhibit 1: Relationships between Shareholders, Board and CEO ..................................................... 42

Exhibit 2: U.S. Disparity between Average Wages and CEO Compensation ....................................... 44

Exhibit 3: Fortune 500 Top 10 CEO Cash Compensation..................................................................45

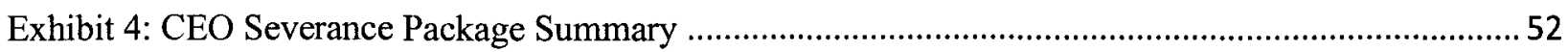

Exhibit 5: 10-Year Growth in Number of Shareholder Resolutions.................................................62 


\section{Introduction}

The recent payment of generous severances to resigning, ousted or retiring CEOs, such as the \$200 million package provided to Hank McKinnell of Pfizer in 2006 and the \$210 million package provided to Bob Nardelli of Home Depot in 2007, and especially those paid by failed U.S. banks, such as Washington Mutual's \$44 million and \$19 million severances to Kelly Killinger and Alan Fishman, respectively, in September 2008, has drawn criticism from investors/shareholders and the public alike (Onaran \& Scinta, 2008; Bank Failures in 2008).

Activist shareholder groups, most notably U.S. labour's AFL-CIO, decry such enormous payments, claiming they are excessive and not in the best interests of shareholders (Herbst, 2006). Some expected that such large severances would end following new disclosure rules adopted by the Securities and Exchange Commission in mid-2006, but the examples above suggest otherwise (Herbst, 2006).

A severance is a company-made payment to an employee whose employment is terminated for a reason other than cause. If shareholders and legislators view these payments as outrageous, why do they continue to occur? Is there a lack of CEO-quality candidates, or a lack of market data with which to compare a CEO's severance package, or a lack of established norms? And, since shareholders are the ultimate owners of these firms, how can their wishes be ignored? What regulations limit executive severances, especially in the case of a CEO who leaves a failing company? What other steps have been taken to ensure that CEO severances are reasonable? 
Furthermore, what is the role of the company's board of directors in setting and/or approving CEO severances? If the role of directors is to represent the interests of the shareholders, are they failing to carry out their fiduciary duties? Is the board and/or the CEO appropriating funds that are rightfully owned by shareholders, on the basis that the CEO has performed all the work and therefore should receive a larger portion of the company's profits?

This paper examines how CEO severance payments are determined in publicly traded Canadian and U.S. companies, who determines them, what, if any, regulatory guidelines must be observed, and will recommend improvements to current practices to eliminate perceived malfeasance. In addition, "golden parachutes", a type of severance provided following a change in control ${ }^{1}$, will be examined to determine whether they are necessary and/or excessive.

\footnotetext{
${ }^{1}$ The term "change in control" refers to the acquisition of one publicly traded company by another, creating job uncertainty for the employees of the acquired company as duplicate positions at the merged firm are eliminated.
} 


\section{Challenges}

This section will examine a number of contributing factors that have created the current CEO severance environment. One or more of the following seven major possible reasons may be causing this environment to exist.

1. Fiduciary Duty of Boards: Boards are not acting in the best interests of shareholders.

2. Managerial Power: CEOs have undue influence over boards, thereby obtaining more lucrative employment contracts.

3. Agency Problem: CEO interests are not effectively aligned with those of shareholders.

4. CEO Shortage: A lack of CEO quality candidates is driving up compensation and increasing a CEO's ability to secure a favourable employment contract.

5. Comparison Data Scarcity: A lack of comparative compensation data is causing boards to provide CEO employment contracts that are too generous.

6. Disempowered Shareholders: Shareholders are unable to control CEO severances.

7. Unclear Profit Ownership: There is a lack of clarity about who owns the profits.

\section{Fiduciary Duty of Boards}

As shareholders are not at the table when CEO employment contracts are struck, they rely on the board of directors to act in their best interests. However, are boards required to act in the best interests of shareholders? It appears not. Legislation dictates that directors are required to act in the best interests of the corporation. It could be argued that acting in the best interests of the corporation and acting in the best interests of the shareholders is synonymous. However, a 2005 Canadian Supreme Court ruling supported the idea that directors must act in the interests of 
the corporation, and that this duty cannot be equated to acting in the interests of shareholders (Peoples Department Stores v. Wise) (Lee, 2005). It is further understood that directors simply represent the interests of shareholders (Osler, Hoskin \& Harcourt LLP, 2009), which is a more passive undertaking.

The plaintiff in a 2007 Canadian court case involving BCE Inc. and debenture holders of one of its subsidiaries, Bell Canada, suggested that directors' fiduciary duty should be interpreted as a duty to represent the interests of all stakeholders, not just shareholders (Aird \& Berlis LLP, 2008). The case was argued in successively higher courts. Eventually, the Supreme Court of Canada overturned the Quebec Court of Appeal's decision and decided that only shareholders' interests needed to be considered (Aird \& Berlis LLP, 2008). This lengthy dispute demonstrates that business people (such as the BCE and debenture holders) continue to interpret the definition of "best of interests of the corporation" differently, and that the courts continue to have difficulty determining what interests directors' fiduciary duties are required to protect.

The corporation's existence as an abstract concept, described by Jensen and Meckling as a "legal fiction" (Jensen \& Meckling, 1976), makes it is possible for directors to take advantage of the fact that the corporation is not clearly represented by any one person or group, nor is the objective of the corporation clear. Jensen (as cited in Keay) poses the question "What are we [the corporation] trying to accomplish?" and states that much debate has arisen over this question (Keay, 2008). This discussion is beyond the scope of this paper, but it is important to recognize the ambiguity surrounding directors' (and officers') fiduciary duties towards the vague being identified as the "corporation", especially as this ambiguity can be taken advantage of by directors and officers in furthering their own interests without concern for the shareholder. As a result, directors may use this distinction to proceed with actions they believe to be in the 
corporation's interest, such as providing employment contracts that provide large severance or change in control payments, which shareholders would argue are not in their best interests.

The lack of a clear indication about "who" the corporation is, and the role of directors with respect to shareholders, have created an extensive body of academic research and opinion papers. A number of theories and models have been developed to explain how corporations should and/or do work.

The shareholder primacy model is still the prevailing view in the U.S. (Lee, 2005). This view holds that a corporation is owned by its shareholders (Keay, 2008) and that therefore directors must act in the shareholders' best interests. This view is supported by a 1989 Delaware Chancery Court ruling that the ultimate objective of directors, acting within the law, must be shareholder wealth maximization (Bainbridge, Unocal at 20: Director Primacy in Corporate Takeovers, 2005).

In the "corporation as nexus" view, Jensen and Meckling state that a corporation is simply "a nexus for a set of contracting relationships among individuals" (Jensen \& Meckling, 1976). Based on this theory, some academics have determined that the role of directors is to "mitigate the conflicts of interests between managers and shareholders" (Matsumura \& Shin, 2005), in effect arbitrating the contractual relationship between and potentially conflicting interests of principals and managers.

Another view is presented by Gulati, Klein \& Zolt, who state that neither of these models is accurate. They contend that the interrelationship of contracts is much more complex than the "nexus of contracts" model (Gulati, Klein, \& Zolt, 2000). They go on to explain that corporations are merely "connected contracts" with no nexus nor governing body, and that 
shareholder primacy or director primacy also do not play a role, and (Gulati, Klein, \& Zolt, 2000). Gulati, Klein \& Zolt's theory further states that there is no firm and no fiduciary duty (Gulati, Klein, \& Zolt, 2000), which we know to be factually incorrect, as these are defined by legal and legislative devices, although other aspects of the model may be valuable representations of the relationships existent in the corporate world.

Lee counters these various theories by arguing that if corporations are permitted to ignore the principle of shareholder primacy, then corporate directors and managers would be able to do as they wish, with accountability to no one. Lee states that this "liberates management to pursue its own interests under the guise of balancing competing interests" (Lee, 2005), as mentioned above.

Bainbridge's "director primacy" model presents a different view still (Bainbridge, Director Primacy and Shareholder Disempowerment, 2006). Bainbridge believes that directors, by virtue of the legislative powers entrusted to them, run the company to the best of their abilities, and that shareholders prefer this structure, because otherwise shareholders would not invest in the company (Bainbridge, Director Primacy and Shareholder Disempowerment, 2006). The director primacy model states that market forces generate supply and demand for various investment opportunities (Bainbridge, Director Primacy and Shareholder Disempowerment, 2006). The fact that many investors continue to invest in corporations is, for Bainbridge, proof that the director primacy model is preferred by investors (Bainbridge, Director Primacy and Shareholder Disempowerment, 2006).

In summary, it appears that directors may be performing their fiduciary duties, although these duties may not be as shareholders understand them to be. Directors' duties are in the 
interests of the corporation rather than shareholders, and a defining Canadian court case (Peoples Department Stores v. Wise) stated that the two interests were not synonymous. It also appears that common law in Canada and the United States have developed on different paths regarding the interpretations of fiduciary duty, as a Delaware court found that corporate activities had to be conducted in the interest of shareholder wealth maximization.

As a result, shareholders wishing to challenge directors for failing to carry out their fiduciary duties towards shareholders in either country will find it an almost impossible challenge; in Canada because the duty is towards the corporation and the interpretation of this is continues to be subject to varying interpretations, and in the United States because the bar for failing to carry out fiduciary duties has been set very high.

\section{Managerial Power}

The examples of CEO compensation and severance previously highlighted cause one to question what occurs during the negotiation of a new CEO's compensation package. Is the board of directors focusing on negotiating a reasonable compensation package or is the board unduly generous or acquiescent in establishing the CEO's compensation package?

Accepting for now that CEO candidates are scarce, as some sources claim, by the time the company has narrowed its pool of candidates to the preferred candidate, the hirer is fairly invested in securing the chosen candidate. It is with this mindset that the board enters into compensation discussions with the CEO candidate.

The other party to the negotiation, the CEO candidate, is likely a highly capable negotiator, another aspect that must be taken into account (Bebchuk \& Fried, 2006). Furthermore, the highly capable negotiator is in possession of information regarding 
compensation levels of other CEOs in the industry and at comparative companies, or any other comparison group that s/he plans to use in negotiating an employment contract, as these are publicly available through SEC and OSC databases. As proxy statements often divulge the comparison companies or comparison group criteria, CEO candidates are likely in possession of exactly the same details as the company's Compensation Committee as both parties enter into negotiations (Dow Jones \& Company, Inc., 1996).

This situation is quite different than that of a Human Resources professional who, in the framework of a well-defined compensation structure, extends a typical offer to a candidate. In the board's case, the board is negotiating an arguably unique compensation package with a person with whom the board will be working closely. Furthermore, more than $60 \%$ of S\&P 500 companies have not separated the role of CEO and Board Chair (The Millstein Center for Corporate Govenance and Performance, Yale School of Management, 2009). As a result, the candidate the board is attempting to secure as the company's future CEO is also likely to be the head of the group offering the compensation package, a powerful role, which adds a distinct complexity to the negotiations. Matsumura and Shin describe the negotiating position of boards as "captive" to the wishes of CEOs, breaching the concept of "procedural fairness" (Matsumura \& Shin, 2005). Bebchuk \& Fried describe this influence as "managerial power" and describe the excess compensation an executive can secure through his/her power over the board as obtaining "rents" (Bebchuk \& Fried, 2006).

The Compensation Committee is in a similar position. It is the Compensation Committee's role to survey comparable companies and determine a suitable compensation package for a new CEO. Although Compensation Committees comprise solely independent 
directors, they may feel the same pressure: that the new $\mathrm{CEO} / \mathrm{Chair}$ will have a great deal of influence over the Compensation Committee directors' ongoing directorships.

It has been found that even compensation consultants are not independent when it comes to advising boards on executive pay ${ }^{2}$. Compensation consultants are acutely aware that the information they provide to Compensation Committees pertaining to executive compensation will dictate whether they will have further business dealings with a company (Bebchuk \& Fried, 2006). As Warren Buffet (as cited in Bebchuk \& Fried) said, compensation consultants "had no trouble perceiving who buttered their bread" (Bebchuk \& Fried, 2006). As a result, compensation consultants present market data that support the compensation figures the CEO, and the Compensation Committee, want to hear to support his/her compensation expectations (Bebchuk \& Fried, 2006). Furthermore, theses outside consultants do not experience a conflict between their duty to shareholders and their wish to please the CEO, since outside consultants have no responsibilities to shareholders (Bebchuk \& Fried, 2006). In fact, when asked what the most significant determinant of current CEO compensation was, directors cited compensation consulting firms as the biggest factor in increasing compensation levels (Lawler III \& Finegold, 2007).

Furthermore, some members of the board are likely executive members, such as the company's CFO or other officer. Recall that legislation dictates a number of independent directors, indicating that most boards are/were stacked with inside directors, and likely still contain a number of inside directors. To these members, the hire of a CEO has twice the

\footnotetext{
${ }^{2}$ Compensation consultants are hired by Compensation Committees to advise the Committee on appropriate levels of executive compensation. Consultants are not part of the board; they are third parties, such as Mercer, Watson Wyatt or Towers Perrin, that make their money by performing compensation surveys of companies and selling it to other companies - company and incumbent names removed. Such consultants may also provide other services to corporations, so any opportunity to get a foot in the door may result in future projects and contracts.
} 
implications; not only will the new CEO preside at the head of the board, but the CEO will oversee their day-to-day activities. Their role in setting their own boss's pay may cause them to be more amenable than if the transaction was at "arm's length", as the goodwill created by a favourable compensation package may contribute to an agreeable working relationship (Bebchuk \& Fried, 2006). Much of the literature regarding CEO compensation and corporate governance describes the CEO pay-setting process as a failure of this negotiation to be at "arm's length" (Bebchuk \& Fried, 2006).

All of the above create a set of complex dynamics. To what extent will these executive and independent board members work towards producing an employment contract that is reasonable and in direct proportion to the skills, knowledge and abilities, accountabilities and risks associated with the role? Research has found that boards tend to provide a generous compensation package to CEOs. In their book "Pay without Performance: The Unfulfilled Promise of Executive Compensation", Bebchuk and Fried explain that directors are more likely to acquiesce when it comes to CEO compensation, as they potentially have much to lose by displeasing a CEO or CEO candidate than they have to gain (Cappiello, 2006). Matsumura and Shin further state that a CEO employment contract obtained in this atmosphere is likely "unethical", violates shareholders rights and may bestow a "grossly inequitable compensation" package (Matsumura \& Shin, 2005).

But what do board members have to lose by pushing for a smaller compensation package with an incoming CEO? First, they stand to lose a positive atmosphere that may set the stage for the overall relationship they will have with the board's chair and CEO. Secondly, they may feel that the new CEO holds sway over whether they continue their role on the board, which may be true, as the CEO could attempt to stack the board with former colleagues or friends (so-called 
“gray" outside directors by Shivdasani and Yermack, 1999, as cited by Matusmura et al) if s/he finds that the existing board is not agreeable (Matsumura \& Shin, 2005). However, Matsumura et al state that NYSE rules preclude a CEO from acting on the Nominating Committee, thereby effectively blocking a CEO's ability to directly stack the board (Matsumura \& Shin, 2005), although indirect approaches would still be possible. Furthermore, as Bebchuk and Fried state (as cited in Cappiello), the CEO is in a position to directly or indirectly benefit directors by sending business their way (Cappiello, 2006); although some directors are retired, others maintain fulltime roles at companies in other industries.

Another reason for board acquiescence to a CEO-preferred employment contract is revealed by recalling how boards themselves are paid. Boards determine their own pay (Bebchuk \& Fried, 2006), using information gathered by the Compensation Committee. Therefore, it may make sense for a board member to agree to a compensation package that is requested by a CEO candidate in the expectation that the same support will be reciprocated when the time comes to review and set board pay. Brick, Palmon and Wald conducted a study to determine whether the level of CEO compensation is related to the level of board compensation. What they found was that the two compensation levels were linked in companies that performed poorly in the market, and where directors did not closely monitor CEO performance, resulting in cronyism between the two parties (Brick, Palmon, \& Wald, 2009).

The same point holds true for executive (inside) directors. The CFO or other company officer who just helped define his/her boss' compensation package might be hoping that the goodwill and largesse extended will trickle down to his or her position as well. 
Distributive justice theory states that society expects that fair procedures are followed in allocating opportunities and rewards so that everyone has a fair chance to be considered (Harris, What's Wrong with Executive Compensation?, 2009). Guth, Schmittenberger and Schwarze's (as referenced in Harris, 2009) 1982 "ultimatum game" study demonstrated that people would rather receive nothing than receive an unfair proportion of a set pool of money, reflecting the importance placed on fairness by society. When CEOs employ managerial influence to achieve their objectives, they breach the rules by which decisions are expected to be made.

In summary, directors feel a substantial amount of subtle, underlying pressure to comply with CEO compensation demands. The risk of backlash from disgruntled shareholders is significantly less, as shareholders have few and difficult avenues available to seriously impact a board's decision or impact directors' board membership. Directors would likely have significant notice of wholesale shareholder dissent, and would have ample time to adopt more agreeable future compensation practices, which would not impact compensation decisions already contracted. Until/unless harsh penalties can be instituted, directors and CEOs will be able to contract agreeable CEO compensation packages.

One tool that could be applied to assess the level of managerial power exercised by a company's CEO, and therefore the impact it has over potential investment returns is Djankov's (et al) "anti-self-dealing index" which provides shareholders with an indication of a firm's level of integrity (Djankov, La Porta, de Silanes, \& Shleifer, 2005). The index, created by an group of independent U.S. law firms, measures disclosure, transaction approvals, private litigation, fines and imprisonment applicable to a company including the regulatory environment in which it operates (Djankov, La Porta, de Silanes, \& Shleifer, 2005). This would permit shareholders to 
decide in advance whether the firm's values match the shareholder's and whether the firm is worth investing in.

\section{Agency Problem}

\section{Agency Theory}

As early as 1776, Adam Smith (as cited in Jensen \& Meckling, 1976) wrote, in The Wealth of Nations, that it could not be expected that managers would guard others' money as well as they would their own (Jensen \& Meckling, 1976). This reference may be the first known recognition of the agency problem, which occurs when the ownership and the management of an item are separated, as is the case with a business into which shareholders invest, and a manager/nonowner becomes responsible for carrying on the work of the business on behalf of the owners/shareholders.

This "agency problem" refers to the difficulty of ensuring that an agent (manager) will always act in the best interests of a principal (owner) (Jensen \& Meckling, 1976), since it is human nature for people to act in their own best interests. In their study, Jensen and Meckling recognize that managers who are not owners attempt to maximize their own wealth and Jensen and Meckling go on to identify the costs associated with the agency problem (Jensen \& Meckling, 1976). In addition to the compensation provided to the executive, agency costs include monitoring costs, bonding expenditures and residual loss (Jensen \& Meckling, 1976). Monitoring costs are the most significant of these, and include costs incurred to monitor the performance of the executive to ensure that duties are performed as required, as well as the costs of implementing structures that define the limits of the CEO's authority, such as budget restrictions and operating guidelines (Jensen \& Meckling, 1976). 
It is not clear whether Jensen \& Meckling refer to officers or directors when they refer to "managers" in their paper, but it is important to note that both directors and officers are agents. Therefore, corporate structure contains two levels of agents: one (directors) that oversees the management of the company, and another (CEO and officers) that manages the company on a day-to-day basis. It may, however, be a case of the fox being in charge of the henhouse, since both parties are agents and neither feels true ownership for the company's resources. This may explain directors' lack of strong incentive to counter CEO demands for increased compensation, as the money they are dispersing is not their own and they do not feel threatened by shareholder actions and repercussions.

The question becomes: What is the correct level of motivation (compensation) that a principal must provide to an agent to encourage actions that are in the principal's best interests? As it pertains to CEO compensation, it can be rephrased as: What is the optimal level of compensation (including base pay, bonus, stock and options) that will align a CEO's interests with the interests of shareholders?

Optimal executive compensation must be defined individually by each company, as there is no one-size-fits-all approach that meets the needs of all companies. Companies need to determine the optimal mix of base salary, short-term incentives (such as bonus), and long-term incentives (such as restricted stock or stock options), as well the levels of each that should be provided.

\section{Examples of the Principal-Agent problem in Corporations}

Examples demonstrate that corporate compensation practices are not achieving full success in aligning CEO actions with corporate interests despite hefty pay cheques, bonuses and 
stock/options, and despite recent safeguards, such as the installation of independent directors and independent Compensation Committees, as dictated by legislative bodies. To illustrate this point, three examples are given below.

Robert Prichard, Torstar's CEO, was apparently acting in his own interest when he renegotiated his employment contract months before he planned to retire in order to receive a $\$ 5.9$ million severance. This action removed funds from the company's coffers that would otherwise have been used to finance capital investments, research and development, shareholder dividends and employee wages.

Anthony Mozilo, Countrywide Financial's CEO of was also acting in his own interests when he started selling his Countrywide stocks in 2006 in order to take advantage of high stock prices before the company's poor credit risk became publicly known and the stock price fell (Sheer, Gullo, \& Levy, 2009). In this case, Mozilo put his interests before the interests of the company, as his attention should have been on keeping the company viable rather than removing his invested capital from the firm.

In a third example, in 1998, four Computer Associates Inc. executives were found guilty of having manipulating revenue (by back-dating the effective dates of contracts) in order to qualify for stock grants (Forelle, 2004). The artificially inflated earnings reports increased the stock price to a level that triggered the stock grants. Once the stock was issued, the company announced a revised revenue forecast that was $\$ 100$ million lower than previously reported, and the stock price fell by two thirds of its previous value (Forelle, 2004; Guidera, 2002; Roberts, Executive pay snafu, 2000). In this case, the CEO and other executives provided misleading information about the company's performance, to their own benefit, and without regard for the 
impact of their actions on the public or the company's shareholders. Executives in this case were able to take advantage of informational asymmetry (a form of organizational injustice) (Harris, What's Wrong with Executive Compensation?, 2009) by not disclosing true earnings to the board so that accurate incentive payments could not be paid out.

\section{Herzberg's and Maslow's Theories}

A number of psychological theories can be applied to the issue of excess in executive compensation. Herzberg's 1959 Motivation-Hygiene theory suggested that certain aspects of work are "hygiene factors". Hygiene factors are aspects of the working arrangement that need to exist to ensure that an employee is not dissatisfied with the employment arrangement (Robbins, 1993). In addition to corporate policies, supervision, working conditions, "hygiene factors" included compensation (Robbins, 1993). Herzberg's study also found that intangible items such as the intrinsic satisfaction of the work, achievement, growth, responsibility and recognition motivated employees to perform better (Robbins, 1993). As a result, the theory found that, provided minimal hygiene needs were met, what motivated employees to achieve better performance results were the intrinsic benefits of performing the work (Robbins, 1993). It is possible that executives have externalized previously intrinsic motivators by seeking to secure more and more compensation for such things as responsibility and recognition inherent in their positions.

Maslow's 1954 "Hierarchy of Needs" theory had produced a similar conclusion (Robbins, 1993). He found that "physiological and safety needs", of which compensation forms a part, were more basic needs (Robbins, 1993). Once these were satisfied, other, higher needs, took precedence (Robbins, 1993). Among those were intangible and non-financial needs: the drive for social fulfillment, esteem and self-actualization, which are similar to Herzberg's "achievement" 
motivator (Robbins, 1993). It is possible that executives' self-actualization (Robbins, 1993) needs include the need to have ever greater salaries and to reach the pinnacle of compensation ranking lists created by organizations such as the AFL-CIO.

Both of these theories, still considered guiding principles of organizational theory today, imply that the various parts of a CEO's compensation can only go so far in ensuring a CEO works hard to achieve organizational objectives and maximize shareholder wealth. Provided the CEO's basic compensation needs are met, further compensation will not achieve greater performance, because compensation is not a motivator. Since any additional compensation does nothing to encourage further effort, compensation provided to CEOs beyond that level may not currently be well utilized, and could be put to better use elsewhere.

\section{More Compensation is Needed}

Some academics and compensation consultants believe that executive compensation in the form of stock ownership is not yet at a sufficient level. Core, Larcker, Guay and Thomas (2005) (as cited in Matsumura and Shin) state that, because CEO compensation in the form of stocks is risky due to its linkage to the market, compensation must be increased still further (Matsumura \& Shin, 2005).

Consultant Dave Bisson, of Presidio Pay Advisors, presents a different view that supports increasing CEO compensation. He believes that for executive compensation to have the effect of causing executives to "think and act like owners", "25 percent to 50 percent of a CEO's total wealth invested in company stock should significantly improve the alignment of executive and shareholder interests" (Bisson, 2009). Bisson's theory is that an effective way of ensuring a CEO's focus on increasing shareholder wealth is to ensure that the majority of his or her wealth 
is tied to the company's performance, that is, he or she does not have a diversified investment portfolio, making his or her investments with the company inherently more risky. This approach is not currently used, as an executive's equity position is usually determined as a percentage of base pay, not his or her individual wealth. Bisson's approach would likely have the effect of increasing executive compensation costs as CEOs are not likely to be individuals with little wealth.

In his article "Are CEOs Overpaid?" Steven Kaplan also argues that CEOs are currently underpaid since the position is subject to an increasing level of risk, scrutiny, criticism and legislation, and that CEOs are increasingly leaving publicly traded companies in favour of the reduced visibility private equity firms provide (Kaplan, 2007).

\section{Summary}

The principal-agent problem continues to be a persistent issue in corporations and has been analyzed extensively in economic, legal, psychological and sociological circles. Greed has become a common influencer of executive compensation levels. Legislation has sought to minimize the effects of the agency problem through greater disclosure guidelines and the introduction of independence requirements for directors and compensation and nominating committees. Executives themselves have acknowledged that executive compensation has become a contentious issue and have established principles to guide boards in setting appropriate compensation levels.

It is possible that the issues currently being experienced with executive pay may spread to director compensation, as they are also agents. This paper has only briefly touched on the topic of director compensation, which is significantly less than CEO compensation. It is possible that 
director compensation will rise as shareholders and regulatory agencies continue to research ways of increasing board and management accountability.

\section{One-Upmanship}

One-upmanship - where one party tries to outdo another - has been a part of the corporate world for centuries. It is an integral part of capitalism; corporations are required to participate in this tactic in order to secure consumers' attention and disposable incomes. For example, in the personal productivity field, Palm's Personal Digital Assistant (PDA) Pilot was supplanted as the market leader by RIM's Blackberry when it incorporated phone capability. RIM now faces competition from Apple's I-Phone, which includes a variety of non-business functions along with telephone and email capability (Nowak, 2009).

One-upmanship occurs in the area of compensation as well. A General Motors executive was quoted in the Wall Street Journal article of saying that, due to an economic downturn in the late 1980s, General Motors was "content to stay in the pack", and that companies were no longer engaging in one-upmanship with respect to expatriate compensation arrangements (Lublin, 1989).

It is possible that the drive for more transparency of executive compensation arrangements for investors has had the unintended consequence of creating an atmosphere of one-upmanship and competition for the highest compensation package. CEOs and CEO candidates have all the information they need to compare themselves with others they wish to out-do. Herzberg and Maslow have demonstrated that financial compensation beyond that required to satisfy basic needs does not motivate enhanced performance. It is therefore theoretically possible that greed replaces satisfaction and dissatisfaction once financial 
compensation exceeds needs or a level that the incumbent perceives as fair. Forbes annual list of highest-paid CEOs, the AFL-CIO's database and other ranking lists may exacerbate the issue, as CEOs can clearly see where they rank in the "hierarchy" of compensation. It is possible that executives see an improvement in their ranking (on any list) as a type of conquest, with them as the victor. A 2008 study by Cozzolino and Snyder found that some individuals were driven by greed, and had to win at any cost, regardless of the situation (Cozzolino \& Snyder, 2008). These people had a "social dominance orientation" that drove them to go so far as to break all the rules in order to ensure a desirable outcome (Cozzolino \& Snyder, 2008). It is possible that some CEOs fall into this category of individuals and will manipulate boards and compensation committees, or falsify financial results (Harris \& Bromiley, Incentives to cheat: the influence of executive compensation and firm performance on financial misrepresentation, 2007), so that they can achieve the top ranking.

\section{CEO Shortage}

Some sources have indicated that CEO compensation and severance packages are so high due to a scarcity of CEO candidates (Useem, 2003). Jensen and Meckling recognized that compensation and agency costs are high when competition is low, and when owners have few other options (Jensen \& Meckling, 1976). However, what are CEO selection criteria and how are CEOs located?

Human resources best practices in recruitment require that a number of preparatory steps be taken before candidates are even interviewed. These include writing a complete Job Description outlining the duties, accountabilities and responsibilities of the role. Furthermore, the skills, knowledge and experience requirements are documented, as are personal attributes that an 
ideal candidate would possess that would make him or her successful in the role. Extroversion is an excellent example of a personal attribute that might be required on the job. This quality does not fall under duties or knowledge, but possessing this quality might make a candidate more successful in a CEO role that requires much social interaction such as attending public events with clients and customers. Do directors perform this ground work?

A second step taken by a human resources professional acting in accordance with best practices is to post the vacancy in a public forum where qualified candidates of all backgrounds learn of the vacancy. A posting could be on-line, or in a publication such as the Globe and Mail. This public approach ensures that qualified women, visible minorities, aboriginals and the disabled (Canada's four designated groups), for example, have equal access to the posting and are able to apply for the position. Do directors perform this step? How do they locate CEO candidates? How do they reach interested and qualified candidates of all backgrounds that may not otherwise be found by the recruiter?

Both of the above steps set the framework for selecting candidates based on objective criteria, not connections or other narrow processes.

It is the role of the Nominating Committee to identify potential CEO candidates. Insufficient information is available about the processes followed by these committees; however, some examples raise questions about the appropriateness of CEO selection processes. Robert Nardelli, Home Depot's CEO from 2000 to 2007, was hired from General Electric, following a contest in which three contenders vied to replace G.E.'s outgoing CEO, Jack Welsh. G.E. selected Jeff Immelt, which left Robert Nardelli as a highly visible CEO candidate for other companies to contemplate (Nardelli's "Severance", 2007). Putting aside for the moment 
Nardelli's appropriateness for the job, it is not clear what processes were followed to identify a pool of qualified candidates for Home Depot's helm. Was Nardelli identified as a potential candidate due to his high visibility in the media? Was Home Depot's entire process based on who was in the public eye? How were other, less visible, candidates solicited? What female or visible minority candidates were considered?

It is likely that Home Depot's Nominating Committee retained an executive search firm to locate potential candidates, which is a common, valid and effective process. However, if the process for directors, who are also identified by the Nominating Committee, is any guide, chances are slim that any qualified less-visible individuals, or those from designated groups were considered. Referring to the director selection process, Chris Bart of The Directors College, states, "far too often, the old boys' network and who you know at the country club still dominates the selection process" (Pooley, 2005). In fact, research by Oakley in 1997 found that only two of the Fortune 500 had female CEOs, and that $97 \%$ of senior managers were white males (Oakley, 2000).

A source from international executive search firm Ray \& Berndtson indicated that placement fees for CEOs are typically $30 \%$ to $35 \%$ of the position's annual base salary ${ }^{3}$. Using figures from Exhibit 3, this results in placement fees ranging from $\$ 420,000$ for the lowest paid CEO (AT\&T) and $\$ 1,155,000$ for the highest paid CEO (G.E) ${ }^{4}$. With such substantial revenue to be gained, search firms are likely to follow the direction provided by their clients (in this case, the board) in order to obtain possible repeat business. If boards do not specifically request

\footnotetext{
${ }^{3}$ The source did not want to be identified, since placement fees are not usually disclosed to non-clients.

${ }^{4}$ I suspect that G.E.'s board would negotiate a more favourable placement fee than the calculated $\$ 1.155$ million since G.E.'s CEO salary is an anomaly among the companies listed in the exhibit: his salary is double that of the other CEOs and includes no cash incentive.
} 
diverse candidates, search firms may pick up on an unspoken wish to maintain the status quo and present candidates the board will feel most comfortable with. In Human Resources circles, this type of preference is termed "same as me" bias, and organizations attempt to avoid this by using the objective selection criteria mentioned above (skills, knowledge and experience).

Furthermore, because the board outsources this task to a search firm, board members may feel distanced from the selection process, which can also reduce the presentation and selection of diverse candidates.

As a result, CEO selection may follow the same process that is used to identify and select board members, namely the "old boys' network" mentioned by Chris Bart of The Directors College.

Changes to status quo CEO selection process may need to start with changes to board composition. While it may appear difficult, an example of mandated changes to board composition is available in Norway. In 2002 , Norway mandated that $40 \%$ of all board seats would be occupied by women by 2009 or non-conforming companies would be shut down (Greenwald, 2009). At the time, working women, who represented $70 \%$ of the population, occupied only $7 \%$ of board seats (Greenwald, 2009). The government's mandate forced companies to consider previously untapped talent, and companies were able to identify and select qualified female candidates without detriment to company performance (Greenwald, 2009). In another example, Quebec has mandated twenty-four crown corporations to achieve $50 \%$ female directorship by 2011 (Manulife Financial Corporation, 2008). In the U.S., a 2007 Catalyst $^{5}$ study of Fortune 500 companies found a high correlation between high female board representation

\footnotetext{
${ }^{5}$ Catalyst is an international organization working towards increasing inclusivity and business opportunities for womenInvalid source specified..
} 
and stronger corporate performance ${ }^{6}$ (Companies With More Women Board Directors Experience Higher Financial Performance, According to Latest Catalyst Bottom Line Report, 2007), making it all the more surprising that boards have not yet increase female board membership from current low levels of $15.2 \%$ to a level that reflects their population in society ${ }^{7}$ (Catalyst 2008 Census of the Fortune 500 Reveals Women Gained Little Ground Advancing to Business Leadership Positions, 2008).

So are qualified CEO candidates scarce? Is it possible that Nominating Committees are considering only a narrow slice of potential candidates, possibly only those with high visibility, or those easily identified in corporate ranks? If this is true, then potential CEO candidates certainly appear to be scarce, which could drive up compensation as market forces drive up the price of a scarce commodity. However, this would not, then justify large severance payments, since employment opportunities for available CEOs would be abundant, or at least ample.

\section{Avallability of Comparison Data}

Is it possible that $\mathrm{CEO}$ compensation is excessive due to a lack of comparison data, requiring Compensation Committees to devise CEO compensation levels out of thin air? It has already been determined that a great deal of comparison information is available through EDGAR, the SEC database for U.S. publicly traded companies, SEDAR, the Canadian Securities Administrators' database, and through Standard \& Poor's ExecuComp.

A review of proxy statements indicates that Compensation Committees can and do call upon compensation consultants, such as Towers Perrin, Hewitt Associates and Watson Wyatt to advise them in determining executive pay levels. Other, more specialized firms also provide

\footnotetext{
${ }^{6}$ Calculated by comparing return on equity, return on sales and return on invested capital.

${ }^{7}$ Women of working age (15-64 years) represent $50.1 \%$ of the U.S. population Invalid source specified..
} 
consulting services with respect to executive compensation, including Equilar and ExeQuity, which also advise on board member pay. Proxy statements of some publicly traded firms also list their comparison group, that is, what companies they compare themselves to, to convey that they have consistent comparison data to use for determining executive compensation (Ford, for example) (SEC's EDGAR database). Others add caveats that permit them room to provide executive compensation that does not align with market data. ExxonMobil, for example, in its 2006 proxy statement, indicated that "the Committee does not use narrow, quantitative measures or formulas in determining compensation levels" (SEC's EDGAR database).

The above information demonstrates that there is no lack of comparative compensation data at the disposal of boards and their Compensation Committees, and this is not a factor that contributes to excessive executive compensation and severance awards.

\section{Disempowered Shareholders}

In the section entitled "Shareholder Discontent and Activism", the numerous avenues open to shareholders to influence CEO compensation and severances are described. These avenues appear narrow and inflexible; for example, shareholders, for the most part, do not have the authority to approve executive pay or severance arrangements, although some shareholders may have won those rights. Historically, however, there was no such disconnect. A 1897 British case (Salomon v Salomon) demonstrates that corporations were originally formed by a small, tightly knit group of founders and their families, who were either at the boardroom table or were represented due to close ties (McQueen, 1999). Because ownership and shareholding fully overlapped, shareholders' interests were naturally taken addressed at the boardroom table. 
In his paper "Director Primacy and Shareholder Disempowerment", Bainbridge states that corporate and business law effectively limits shareholders from participating in corporate governance and decision making, meaning that "director primacy" governs the way corporations are run (Bainbridge, Director Primacy and Shareholder Disempowerment, 2006). Citing the law of supply and demand, he argues that this "director primacy" model is preferred by shareholders, because otherwise shareholders would place their money with other forms of investment (Bainbridge, Director Primacy and Shareholder Disempowerment, 2006). It may be possible that shareholders invest in corporations despite the limitations corporations impose on shareholder participation because the returns exceed the value of having a greater say, although shareholders would prefer both. Another view is that shareholders may not have many investment options because well-defined regulatory frameworks govern how companies can operate. On the other hand, perhaps Bainbridge's view is correct, that shareholders prefer to remain uninvolved in corporate governance, and that recent events have caused them to become more vigilant over their investment returns, which has forced their active participation in corporate governance matters. Shareholders are limited in their recourse: they can seek to partake in governance activities or, if this role is not welcomed by boards, they can seek to change the regulatory framework surrounding corporate operations. One aspect that influences shareholders' ability to effectively participate in board decision-making is that informational asymmetry (Harris, What's Wrong with Executive Compensation?, 2009) hampers shareholders' abilities to understand board events and deals, leaving them to complain once it is too late.

Regardless, the corporate landscape has now changed. Examples of executive excess and greed and perceived board ambivalence and inaction have become commonplace, and shareholders, especially institutional investors, who represent pension funds, insurance 
companies, mutual fund companies and brokerages (Institutional investor definition) and carry significant voting power, have determined that it is imperative to carefully monitor board and management activity to ensure that it delivers on its legally mandated objective of increasing shareholder wealth.

\section{Unclear Profit Ownership}

Basic accounting rules indicate that any funds remaining from revenue beyond those required to pay for material costs, wages, other expenses and dividends become retained earnings and are added to the section entitled owners' equity on the balance sheet (Corrado, Jordan, \& Yuce, Fundamentals of Investments Valuation and Management, Canadian Edition, 2006). Retained earnings are then reinvested into the company for future growth (Corrado, Jordan, \& Yuce, Fundamentals of Investments Valuation and Management, Canadian Edition, 2006).

From a shareholder's perspective, then, it would appear that any amounts beyond those reasonably required to run the company could alternatively be paid out in larger shareholder dividends or used to increase the company's market competitiveness through enhanced marketing programs or investment in research and development or capital equipment. Amounts spent on executive compensation beyond that required to motivate the CEO to meet corporate objectives do not meet shareholders' expectations for corporate growth or shareholder wealth maximization.

On the other hand, since "nobody owns the corporation" (Pruijm) and directors are not accountable to shareholders but rather to the nebulous entity called "corporation", corporate executives and their boards may deem any profit garnered by the company to belong to the corporation itself, subject to acquisition by whoever can access it. Furthermore, perhaps boards 
have decided that any profits beyond those required to provide shareholders with an expected amount of dividends can be utilized at their discretion. Not only would this support the idea that boards can provide excessive compensation to the CEO, it also implies that boards may increase their own compensation in the future. This concept is not unrealistic, as the same forces apply to director pay that apply to CEO pay: 1) influence over the amount, 2) broadly available competitive market information, and 3) need to pay sufficient compensation to compensate for the principal-agent problem. 


\section{Legislative Framework}

To fathom the origins of these issues it is necessary to understand how today's corporations are structured and managed, and how and by whom major corporate decisions are made. Important to note is the level of information disclosure, accountability, consultation and decision making involvement between three groups: directors, officers and shareholders. Where currency is referenced, figures of Canadian companies have been presented in Canadian currency and figures of U.S. companies have been presented in U.S. currency.

\section{Canada: Overview of Publicly Traded Companies and the Role of Directors}

In Canada, publicly traded companies are governed by a variety of laws, rules and regulations. For example, legislation governing Canadian corporations that are publicly traded on Canada's largest securities exchange, the Toronto Stock Exchange (Government of Canada), include the provincial Business Corporations Act, the provincial Securities Act and the provincial Commodities Futures Act. Some industries are governed by additional legislation, such as the banking industry. The following section will present only regulatory requirements applicable to this discussion; requirements exist that extend far beyond the current undertaking, such as compliance to financial reporting regulations.

The Toronto Stock Exchange (TSX") is the third largest exchange in North America (Government of Canada). To become listed with the TSX, companies must meet the listing criteria set out in the TSX Company Manual (TSX). The TSX Company Manual requires that listed companies have, at a minimum, the following roles: a CEO, a CFO that is not the same person as the CEO, a corporate secretary, and two independent directors (TSX). 
The TSX defines the term "independent director" as a person who is not a member of management and does not have a material business relationship with the company; is not an officer, employee or major shareholder of a company that has a material business relationship with the company; is not and has not been an officer, employee or service provider to the company or its affiliates for the past three years; and, does not own more than ten percent of the company's votes (TSX).

In addition to the TSX requirements, the Ontario Securities Commission ("OSC") requires each listed company to have an Audit Committee that is comprised of three independent directors (Ontario Securities Commission, 2004), thereby increasing the number of independent directors required from two to three. The OSC defines the term "independent director" as a person who does not have or has not had a material relationship with the company within the past three years (Ontario Securities Commission, 2004).

The role of the Audit Committee is to recommend an external financial auditor and to directly oversee the external auditor's work (Ontario Securities Commission, 2004). In addition, the Audit Committee is responsible for determining compensation paid to the members of the board of directors and what level of fees will be paid to the external auditor (Ontario Securities Commission, 2004). It is further tasked with reviewing the company's annual and quarterly financial statements (Ontario Securities Commission, 2004). The Audit Committee must also review the external auditor's hiring procedures to ensure that qualified people have performed the work (Ontario Securities Commission, 2004). For example, if the external financial auditor is KPMG, the Audit Committee of Company A must assess KPMG's hiring controls to ensure that only people with appropriate qualifications, such as Chartered Accountants, or Certified Public Accountants, prepare Company A's financial statements. This ensures that Company A 
understands it has full accountability for the accuracy of its financial statements, and cannot claim that its financial auditor was at fault for any potential oversights.

Both the TSX and the OSC have defined what makes a director independent, but the duties and responsibilities of a director have yet to be defined. For this, the analysis must turn to the Canada Business Corporations Act ("CBCA"). Incorporation is one method of conducting business in Canada, and has the benefit of limiting owner liability and may result in lower taxes than individual taxation (Industry Canada, 2009).

In Canada, incorporated companies are registered under one of the provincial Business Corporations Acts. The CBCA provides minimum guidelines with which each provincial Act, and therefore corporation, must comply (Department of Justice Canada, 2009). The CBCA states the following with respect to directors:

- A publicly traded company must have a minimum of three directors, at least two of which must not be employees of the company or associated companies (s 102),

- Duties of directors are to manage, or to oversee the management of, the corporation and its affairs (s 102),

- Subject to shareholder approval, directors may create, change or repeal corporate by-laws (s 103),

- Directors may appoint a managing director, and (a) committee(s) (s 115),

- Directors may appoint, define the duties of and bestow powers on officers to manage the company. That these officers may simultaneously be directors (s 121), 
- Directors must "act honestly and in good faith with a view to the best interests of the corporation" (s 122). This responsibility is termed "fiduciary duty" (Osler, Hoskin \& Harcourt LLP, 2009),

- Directors must "exercise the care, diligence, and skill that a reasonably prudent person would exercise in comparable circumstances" (s 122). This responsibility is termed "duty of care" (Osler, Hoskin \& Harcourt LLP, 2009),

- Directors must disclose to the company any material interest in a contract or transaction that involves the company and another entity (s 120),

- Directors must comply with any unanimous shareholder agreements, the CBCA and associated regulations, and the company's bylaws and articles of incorporation (s 122),

- Directors may determine the compensation payable to directors, officers and employees, subject to the articles, bylaws and any unanimous shareholder agreement (s 125),

- Directors may be elected to hold office for a maximum period of three years (s 106) (they may serve additional terms provided they are re-elected to serve on the board),

- It is not required for directors to hold shares in the company (s 105) (Department of Justice Canada, 2009).

The majority of boards also assign a chair that is responsible for running board meetings, setting the agenda and ensuring that board members are suitably informed about the company's business affairs (Osler, Hoskin \& Harcourt LLP, 2009).

\section{officers}

Officers are charged with managing the business affairs of the company (Department of Justice Canada, 2009). As mentioned above, these officers minimally include the CEO and CFO, as 
required by the TSX. The CBCA sets certain limitations on the powers of officers, including that officers may not appoint directors, issue securities or shares, buy back the company's shares, approve financial statements, amend bylaws, approve the purchase of the company by another, declare dividends or submit any issue for shareholder consideration (s 115) (Department of Justice Canada, 2009).

In addition, officers, like directors, must:

- Meet the fiduciary duty and duty of care requirements outlined above,

- Disclose to the company any material interest in a contract or transaction that involves the company and another entity (s 120),

- Comply with any unanimous shareholder agreements, the CBCA and associated regulations, and the company's bylaws and articles of incorporation (2 122) (Department of Justice Canada, 2009).

\section{Shareholders}

The term "shareholder" (also known as "stockholder") is defined by Webster's New World Law Dictionary as "a person who owns one or more shares of stock in a joint-stock company or a corporation" (Webster's New World Law Dictionary, 2006). Shareholders' rights and duties are defined in the CBCA, as follows:

- Shareholders may change the articles of incorporation (s 112),

- Shareholders may change the number of directors of the company (s 112),

- Shareholders may elect and/or remove directors (s 106, 109),

- Shareholders may view any directors' meeting minutes in which conflict(s) of interest are disclosed (s 120), 
- Shareholders may create, change or repeal bylaws (s 103),

- Shareholders possessing shares that carry voting rights are entitled to be invited to, attend and vote at the company's annual general meeting, and special shareholder meetings ( $\mathrm{s}$ $133,134,149)$

- Shareholders are entitled to review the company's audited financial statements and auditor's report, and approve the company's selection of financial auditor (s 135, 155),

- Registered/beneficial shareholders may submit, or raise in person, a proposal(s) for consideration at the annual general meeting (s 137),

- Shareholders are permitted to assign their vote to another party to exercise ("proxy") (s 148) (Department of Justice Canada, 2009).

\section{United States: Overview of Publicly Traded Companies and the Role of}

\section{Directors}

In the United States, publicly traded corporations must comply with a host of securities related laws ${ }^{8}$, the requirements of the Business Corporation Law of the state in which the company is registered, as well as the exchange on which it is listed.

The New York Stock Exchange ("NYSE"), the world's largest stock exchange, has specified the following requirement for companies listed on its exchange (World's largest stock exchanges, 2007).

The majority of directors on a board of directors must be independent members (NYSE). Board members are deemed independent if they have not been employed by the company within

\footnotetext{
${ }^{8}$ These include the 1933 Securities Act, 1934 Securities Exchange Act, 1939 Trust Indenture Act, and the 2002 Sarbanes-Oxley Act (U.S. Securities and Exchange Commission, 2008).
} 
the last three years, and do not have an immediate family member who is or has been an executive officer of the firm in the last three years (NYSE). In addition, they are deemed independent if all other members of the board can unequivocally state that the member "has no material relation with the listed company" (NYSE). Independent directors are required to hold regular meetings that do not include management directors (NYSE).

Each listed company is required to appoint three committees that are comprised solely of independent board directors, and each committee is required to have a charter that defines its role in accordance with minimum New York Stock Exchange rules (NYSE). These three committees are: the Audit Committee, the Nominating and Governance Committee, and the Compensation Committee (NYSE). The board has the authority to establish additional committees as the need arises (NYSE).

The Audit Committee must have a minimum number of three financially literate directors (NYSE). The Audit Committee is responsible for selecting a qualified, independent audit firm to audit the company's annual financial statements, overseeing the company's legal and regulatory compliance, and overseeing the integrity of the company's financial statements (NYSE). The Audit Committee is required to produce a report to be included in the annual proxy statement to inform shareholders of the financial health of the company (NYSE).

The Nominating and Governance Committee is responsible for setting criteria for board membership, identifying and presenting candidates for election to the board, developing corporate governance guidelines, and overseeing the evaluation of management and the board (NYSE). 
The Compensation Committee is responsible for defining performance objectives, determining compensation structures, and assessing performance of the CEO relative to the objectives (NYSE). In addition, the Compensation Committee "makes recommendations to the Board regarding non-CEO executive officer compensation" plans (NYSE). The Compensation Committee is also required to produce a report that will form part of the annual proxy statement to inform shareholders of compensation pertaining to executive officers of the company (NYSE).

Further information about board director duties, responsibilities and guidelines can be gleaned from the Delaware General Corporate Law (DGCL). Because U.S. corporations are free to chose any state in which to incorporate, "more than $50 \%$ of all U.S. publicly traded companies and $63 \%$ of the Fortune 500" (Delaware Division of Corporations) are incorporated under this law (Booth, 2008 (Forthcoming); Division of Research of Legislative Council of the General Assembly, 2009).

Subchapter IV Directors and Officers of the Delaware General Corporate Law provides that:

- The board of directors be comprised of one or more directors, the number of which is determined first by the certificate of incorporation, otherwise by the company by-laws,

- The company's business will be managed by, or overseen by, a board of directors, unless otherwise stated in the certificate of incorporation,

- Directors are not required to hold stock unless required to do so in the corporation's certificate of incorporation or by-laws,

- Directors may remain on the board for an indeterminate period of time,

- Directors may implement committees consisting of one or more board members, 
- Unless otherwise specified in the certificate of incorporation or the bylaws, directors determine director compensation,

- Directors (or other governing body) appoint officers of the company, unless otherwise specified in the bylaws,

- A director may engage in contracts or transactions with the company or its affiliates provided that $\mathrm{s} / \mathrm{he}$ has disclosed a conflict of interest, and that the majority of disinterested directors approve the contract or transaction, regardless if a quorum of directors is present (Division of Research of Legislative Council of the General Assembly, 2009),

- Directors may create, change, repeal and implement bylaws if this is specified in the company's certificate of incorporation (s 109) (Division of Research of Legislative Council of the General Assembly, 2009).

\section{offeces}

Little is stated in the DGCL regarding the duties and responsibilities of officers. The only reference to officers located in the DGCL provides that officers:

- May hold office as long as the bylaws, directors or other governing body dictate (s 142) (Division of Research of Legislative Council of the General Assembly, 2009).

\section{Shareholders}

Under DGCL, shareholders have the following duties, responsibilities and rights:

- Receive dividends as specified by the board of directors (s 151),

- Receive a share of the assets of a dissolved companied (s 151),

- Shareholders may elect directors at annual general meeting (s 211), 
- Attend shareholder meetings, including special shareholder meetings (s 211),

- Authorize another person to vote on their behalf by proxy (s 212),

- Receive notice of a meeting of shareholders (s 222) (Division of Research of Legislative Council of the General Assembly, 2009),

- Remove directors (s 141) (Division of Research of Legislative Council of the General Assembly, 2009),

- To implement, change and repeal bylaws (s 109) (Division of Research of Legislative Council of the General Assembly, 2009).

Furthermore, the NYSE provides shareholders with the power to authorize the company's equity compensation plans (NYSE, 2004). An equity compensation plan is defined as "a plan or other arrangement that provides for the delivery of equity securities (either newly issued or treasury shares) of the listed company to any employee, director or officer or other service provider as compensation for services" (NYSE, 2004).

\section{Chief Executve Office and Relationship to the Boand}

Since the topic of this paper is the severance and compensation paid to the role of Chief Executive Officer, it is important to define it separately from the larger group defined as "officers", which includes roles such as chief financial officer (CFO) and chief operating officer (COO).

The chief executive officer (CEO) is chosen by the board of directors, is charged with the daily running of the company and is accountable to the board (Osler, Hoskin \& Harcourt LLP, 2009). It is the CEO's role to carry out the objectives defined by the board, and keep the board 
updated on the business as well as issues facing the corporation (Osler, Hoskin \& Harcourt LLP, 2009).

In Canada, the role of CEO and Board Chair may legally be performed by the same person (Ontario Securities Commission, 2004). However, in its Corporate Governance Guidelines, the OSC recommends that these two roles be separated to permit board and management responsibilities to be clearly delineated (Ontario Securities Commission, 2004). A 2003 study found that the role of CEO and Board Chair roles had been separated by $66 \%$ of 300 Canadian publicly traded companies (The Millstein Center for Corporate Govenance and Performance, Yale School of Management, 2009).

In the United States, corporations are also to date not required to separate these roles (The Millstein Center for Corporate Govenance and Performance, Yale School of Management, 2009). Research revealed that less than $40 \%$ of S\&P 500 companies have separated these roles (The Millstein Center for Corporate Govenance and Performance, Yale School of Management, 2009).

\section{Comments regarding Canadian and U.S. Corporate Law}

The Canadian overview above includes select pertinent statutory law governing publicly traded Canadian corporations. In addition to statutory law, the Canadian legal system is founded on common law (except Quebec, which is governed by civil law), which permits the courts to make decisions where legislation fails to provide a clear answer (Statistics Canada, 2004). Case law on this subject is too vast to include here. Further sections of this paper will make reference to court decisions as necessary to advance the discussion of CEO severances. 
The Canadian and U.S. corporate overview provided above demonstrates that the legislative framework and roles of directors, shareholders and officers are substantially similar between Canada and the United States, although different legislative bodies govern. Both countries have a corporate law system that consists of a combination of legislation and case law, and regulation governing the public trading of shares, although in Canada the Business Corporations Act dictates more board and officer accountability than does the DGCL. In the United States, many of these requirements are detailed in SEC requirements.

Delaware General Corporate Law provides incorporators with significant flexibility in defining how corporations are organized and run, as many clauses permit the company's articles of incorporation and bylaws to override the DGCL's provisions. In addition, the concepts of fiduciary duty and duty of care do not seem to be engrained in the DGCL as a search for the terms "honest", “ethic", "moral”, "diligence", “competent", "duty", "fiduciary" did not produce any results. It is not, therefore, surprising that, in the past, some companies ${ }^{9}$ took advantage of the lack of board and management accountability, causing scandals and resulting in the 2002 Sarbanes-Oxley Act, the intent of which is to "protect investors by improving the accuracy and reliability of corporate disclosures", and which is enforced by the Securities and Exchange Commission (Public Law 107-204 - July 30, 2002, 2002). The NYSE's Listed Company Manual contains entire sections devoted to corporate governance and business conduct and ethics (NYSE). However, a just released finding by the Court of Chancery in Delaware regarding the "fiduciary duties of care and loyalty" indicated that both directors and officers in the United States are bound by these duties, but that the extent of liability differs in that directors' liability

\footnotetext{
${ }^{9}$ Enron, Worldcom.
} 
can be eliminated through charter document provisions, whereas corporate officers remain exposed to this liability (Kaufer \& Radell, 2009).

\section{Summary}

The foregoing information was a necessary introduction to this paper, so that the relationships between the roles of directors, shareholders and officers is understood with respect to information disclosure, accountability, consultation and decision making. The summary permits some pertinent observations to be made regarding the structure of the relationships between shareholders, directors and CEO of a company.

- That the board of directors selects the company's CEO from a pool of candidates put forward by the Nominating Committee,

- That the board of directors sets the CEO's employment contract (which includes pay and incentives, and severance arrangements if the relationship fails), based on input received from the board's Compensation Committee,

- That the inclusion of independent directors on the board of directors is mandated by law, implying that boards previously consisted solely of management directors, possibly leading to management entrenchment and resulting in cronyism,

- That information is provided to shareholders in a structured format, and as dictated by law, implying that information is otherwise not likely to be shared,

- That shareholders meet with directors at minimum only annually,

- That there is no explicit statement that directors represent the interests of the shareholders, 
- That there is no explicit statement that directors and officers are accountable to shareholders.

These observations are necessary to the subsequent discussion of the issues involved in CEO compensation. Exhibit 1 provides a visual depiction of the relationships between the CEO, shareholders and board of directors (including CC-Compensation Committee, NGC-Nominating and Governing Committee and AC-Audit Committee).

The image reflects that, of the board members, the CEO is simultaneously: a member of the board, a shareholder (through wage incentives) and a member of the company. In this depiction, the CEO is the only executive, or inside, member of the board, although it is possible for other inside directors to be on the board. Also, the image shows the various committee members as independent members and shareholders.

\section{Exhbit 1: Relationships between Shareholders, Board and CEO}

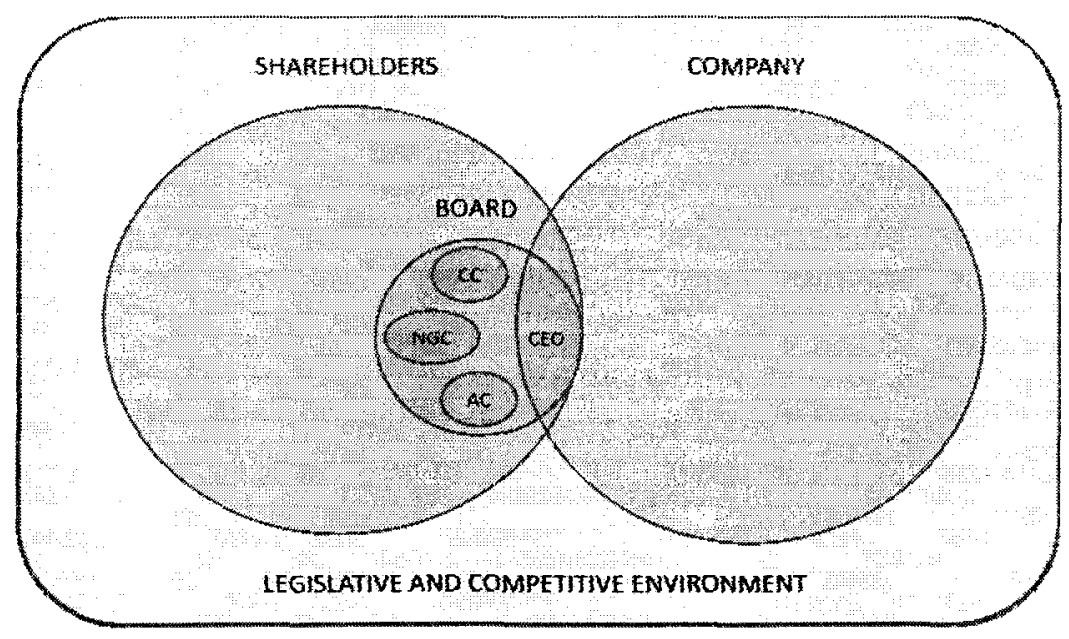




\section{Growth of CEO Base Salaries and Severances}

Executive compensation is comprised of a number of components. In addition to base salary and benefits (health, dental, life and disability insurances, for example), executives are rewarded with perquisites (usually referred to as perks), short term incentives and long term incentives (American Compensation Association (WorldatWork), 1998). Examples of perks are a car allowance or the use of a company car or plane, golf club membership, financial and retirement planning assistance, and a supplemental executive retirement plan (SERP) (American Compensation Association (WorldatWork), 1998).

Short-term incentives are usually structured to award an executive for achievement of business performance goals that can be attained within one year (American Compensation Association (WorldatWork), 1998). Examples of a short-term incentive are bonuses paid based on the annual achievement of a corporate revenue target, net income target, the achievement of a sales target pertaining to a specific product, earnings per share or market share (American Compensation Association (WorldatWork), 1998).

Long-term incentives are paid for achievement of goals that take a longer time to achieve, and may be paid out in cash or equity stakes (stock or stock options) in the company (American Compensation Association (WorldatWork), 1998). The objective of long-term incentives is to retain the executive over the long term. Equity stakes achieve this result more effectively than cash bonus payments (as lost cash bonuses can be compensated for by a new employer that attracts an executive away), and also help align an executive's interests with long-term shareholders' interests. 
Base salaries, upon which most severance calculations are based, are already in the millions of dollars. An August, 2008 study found that in 2007 S\&P 500 CEOs received 344 times the income received by the average U.S. employee, and that the average CEO pay was calculated at $\$ 10.7$ million (Anderson, Cavanagh, Collins, Pizzigati, \& Lapham, 2008). Data collected by Dow Jones between 1965 and 1995 demonstrated the exponential growth in disparity of income levels between these two groups (Exhibit 2).

\section{Fxhibit 2: U.S. Disparity between Average Wages and CEO Compensation}

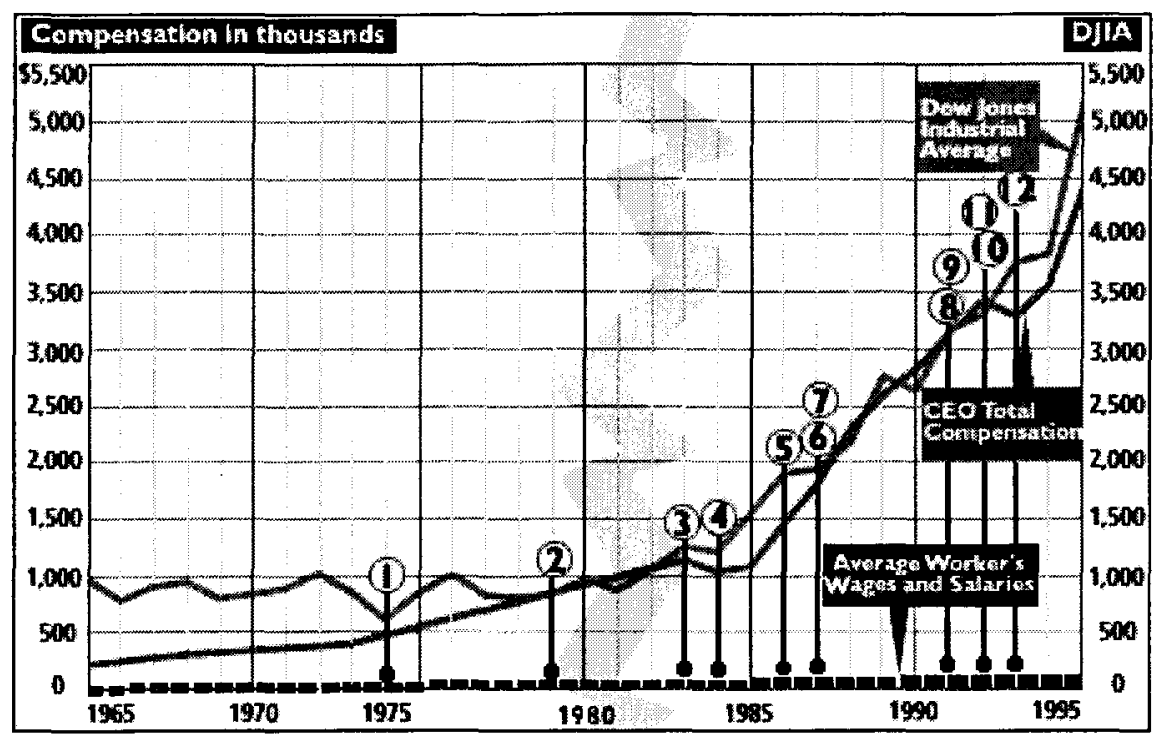

Source: (Dow Jones \& Company, Inc., 1996)

A number of organizational justice theories may explain why shareholders, employees and the public at large are incensed and outraged over this disparity. Proponents of the theory of distributive justice, which deals with the fair distribution of wealth and opportunity, would assert that the outrage is due to our innate sense of fairness. Organizational justice theories are more fully explored in the section entitled "Challenges". 
In Canada, a study published by the Canadian Centre for Policy Alternatives in December 2007 found that Canada's 100 best paid CEOs made an average of $\$ 8.5$ million in 2006, where the top CEO made $\$ 54.7$ million and the lowest paid CEO received $\$ 3$ million (Mackenzie, 2007). The study found that these CEOs earned 218 times the income of an average Canadian (Mackenzie, 2007) ${ }^{10}$. To illustrate this point, cash compensation provided to CEOs of the top ten U.S. Fortune 500 companies are shown in Exhibit 3.

\section{Exhibit 3: Fortune 500 Top 10 CEO Cash Compensation}

\begin{tabular}{|c|c|c|c|c|c|c|}
\hline $\begin{array}{c}\text { U.S. Fortune } 500 \\
\text { Rank/Company } \\
\text { Name }\end{array}$ & President/CEO & Base Pay & $\begin{array}{l}\text { Bonus + Non- } \\
\text { Equity } \\
\text { Incentive } \\
\text { Compensation }\end{array}$ & $\begin{array}{c}2008 \text { Total } \\
\text { Annual Cash } \\
\text { Compensation } \\
{ }_{11}\end{array}$ & $\begin{array}{c}2008 \\
\text { Revenues } \\
(\$ \text { in } \\
\text { millions })^{12}\end{array}$ & $\begin{array}{c}2008 \\
\text { Profits } \\
\text { (\$ in } \\
\text { millions })\end{array}$ \\
\hline 1. Exxon Mobil & $\begin{array}{l}\text { R.W. Tillerson } \\
\text { Chairman and CEO }\end{array}$ & $1,870,000$ & $4,000,000$ & $5,870,000$ & 442,851 & 45,220 \\
\hline 2. Wal-mart Stores Inc. & $\begin{array}{l}\text { H. Lee Scott } \\
\text { President and CEO }\end{array}$ & $1,456,000$ & $5,824,000$ & $7,280,000$ & 405,607 & 13,400 \\
\hline 3. Chevron & $\begin{array}{l}\text { David J. O'Reilly } \\
\text { Chairman and CEO }\end{array}$ & $1,650,000$ & $3,600,000$ & $5,250,000$ & 263,159 & 23,931 \\
\hline 4. ConocoPhillips & $\begin{array}{l}\text { James J. Mulva } \\
\text { Chairman and CEO }\end{array}$ & $1,500,000$ & $1,417,500$ & $2,917,500$ & 230,764 & $-16,998$ \\
\hline 5. General Electric & $\begin{array}{l}\text { Jeffrey Immelt } \\
\text { Chairman and CEO }\end{array}$ & $3,300,000$ & 0 & $3,300,000$ & 183,207 & 17,410 \\
\hline 6. General Motors & $\begin{array}{l}\text { G.R. Wagoner Jr. } \\
\text { Chairman and CEO }\end{array}$ & $1,558,333$ & $1,802,000$ & $3,360,333$ & 148,979 & $-30,860$ \\
\hline 7. Ford Motor & $\begin{array}{l}\text { Alan Mulally } \\
\text { President and CEO }\end{array}$ & $2,000,000$ & 0 & $2,000,000$ & 146,277 & $-14,672$ \\
\hline 8. AT\&T & $\begin{array}{l}\text { Randall Stephenson } \\
\text { Chairman, CEO \& } \\
\text { President }\end{array}$ & $1,420,833$ & 0 & $1,420,833$ & 124,028 & 12,867 \\
\hline 9. Hewlett-Packard & $\begin{array}{l}\text { Mark Hurd } \\
\text { Chairman, CEO \& } \\
\text { President }\end{array}$ & $1,450,000$ & $23,931,882$ & $25,381,882$ & 118,364 & 8,329 \\
\hline 10. Valero Energy & $\begin{array}{l}\text { William Klesse } \\
\text { CEO }\end{array}$ & $1,500,000$ & 705,510 & $2,205,510$ & 118,298 & $-1,131$ \\
\hline
\end{tabular}

Sources: (Salary.com Executive Compensation Wizard; Fortune 500, 2009; AFL-CIO's CEO Pay Database)

\footnotetext{
${ }^{10}$ The study also found that CEO pay grew by $146 \%$ from 1998 to 2006, whereas an average Canadian's income only grew by $18 \%$ during the same period (Mackenzie, 2007).

${ }^{11}$ Salary data for fiscal year ended in 2009

${ }^{12}$ Company performance figures for 2008 fiscal year
}

Corporate Governance Issues Surrounding Executive Compensation and Executive Severance

Andrea W. Zanetti

Page 45 
The issue of excess CEO severance has been a concern for many years. In the early 1980s an excise tax was introduced in the United States to penalize any severance that was greater than 2.99 times salary and bonus, following the then-highest ever severance awarded, $\$ 4$ million, to William Agee of Bendix in the early eighties (Thornton, 2005). A 2.99 multiple maximum means that a severed CEO should receive no more than just under three years' annual wages to compensate for his/her forced departure.

Some believe that the introduction of this 1984 excise tax set a new standard for severances, causing many companies to automatically calculate CEO severances at 2.99 times base salary and bonus (Dow Jones \& Company, Inc., 1996). This guideline is still used as a standard today in determining CEO severances (Morgenson, 2005). To illustrate the size of severances that might result from the hypothetical forced departure of Fortune 500 CEOs, a calculation using today's total annual cash compensation figures from Exhibit 3 multiplied by 2.99 would produce severances ranging from $\$ 6.6$ million to almost $\$ 76$ million.

A number of subsequent legislative changes in the United States that were designed to control CEO compensation had the opposite effect. For example, in 1992, the Securities and Exchange Commission issued a ruling requiring greater compensation disclosure in proxy statements, with the intent of providing shareholders with greater insight, but the ruling, in effect, provided other CEOs with clear compensation data with which to compare their own compensation packages, which inadvertently caused an increase in CEO compensation (Dow Jones \& Company, Inc., 1996). Again in 1993, a U.S. tax law aimed at capping CEO compensation at $\$ 1$ million by limiting corporate wage expense deductibility to this amount inadvertently resulted in boards increasing CEO pay to this level (Dow Jones \& Company, Inc., 1996). Even today, most CEO base pay remains just above the $\$ 1$ million mark, as can be seen in Corporate Governance Issues Surrounding Executive Compensation and Executive Severance Andrea W. Zanetti 
Exhibit 3. The other impact of this tax was that companies wanting to cap CEO pay at $\$ 1$ million in order to avoid the tax opted to provide more compensation in the form of stock options (Hood, 2009).

\section{High Profile Canadran CEO Severances}

In Canada, three recent notable cases have focused investor attention on CEO severances.

In 2008, Michael Sabia retired from BCE Inc., with a \$21 million package that included severance, accelerated stock options and incentives (Avery \& McFarland, 2009; Tomesco \& Alexander, 2009; BCE, 2009). Sabia had been with the company's CEO for six years (BCE, 2009).

In May 2009, Dominic D’Alessandro of Manulife Financial retired with a \$12.6 million severance package (Avery \& McFarland, 2009). He had been with the company for fifteen years (Avery \& McFarland, 2009).

In 2008, Robert Prichard, Torstar's CEO for the past seven years, resigned, leaving with \$9.58 million (Avery \& McFarland, 2009; Taylor, 2009) in accordance with the terms of his employment contract. He had renegotiated his contract with the board in early 2008 so that he would receive the same termination package regardless of whether he resigned or was terminated without cause (Taylor, 2009).

\section{High Profile U.S. CEO Severances}

Examples from the United States tend to involve higher figures than most Canadian cases. The following is a list of some recent examples. 
- In 2005, after five years of service, James Kilts parted from his employer, Gillette Inc., with a $\$ 165$ million payout (Maremont, 2005). Kilts had solicited the acquisition of Gillette by Procter \& Gamble, and received a reported $\$ 12.6$ million change in control payment as part of his $\$ 165$ million departure package (Maremont, 2005).

- In December 2005, Lee Raymond retired from ExxonMobil with an estimated \$351 million payout (Moran \& Yap, 2007). During his 12 years at the helm, ExxonMobil became the largest oil company and second largest (by revenue) publicly traded company (after Wal-Mart) in the world (Moran \& Yap, 2007; Fortune Magazine, 2008). The retirement package is considered one of the biggest ever (Oil: Exxon Chairman's $\$ 400$ Million Parachute, 2005). Raymond had been with the company for 42 years (SEC's EDGAR database).

- In November 2006, Bruce Karatz left KB Home with an estimated severance package of \$163 million (Herbst, 2006) after 34 years with the firm. He had been both Chair and CEO at the time of his departure (SEC's EDGAR database).

- In January 2007, Bob Nardelli left Home Depot with $\$ 210$ million (Home Improvement Can Get Very Messy, 2007). The departure followed a period of severe criticism of Nardelli's high compensation (Home Depot CEO Nardelli quits, 2007). The previous year's proxy statement included a number of shareholder resolutions aimed at curbing executive compensation and retirement benefits, which were rejected (SEC's EDGAR database; Home Depot CEO Nardelli quits, 2007). During his tenure, he was simultaneously Board Chair and CEO. Home Depot is one of the many U.S. corporations that are registered under DGCL (SEC's EDGAR database). 
- In October 2007, following a period of corporate losses, Stan O'Neal retired as Chair and CEO of Merrill Lynch after 21 years with the company, the last five years as CEO, with a retirement package totaling \$161.5 million (Moran \& Yap, 2007; Moyer, 2007).

\section{CLO Severance Refusals}

Others have refused severances even though they had previously been negotiated. The rejection of these severances is understandable in light of the fact that these financial lenders and investment companies did (or almost) become bankrupt at the time of their departure ${ }^{13}$. They include:

- Angelo Mozilo of Countrywide Financial forfeited $\$ 37.5$ million in the face of shareholder and public criticism following the purchase of the failing mortgage lender by Bank of America in 2008 (Hagerty, 2008).

- In June 2008, Robert Willumstad of AIG turned down his promised $\$ 22$ million severance package, citing his failure to successfully restructure the company into profitability (Gomstyn, 2008).

- Also in 2008, Alan Fishman refused to accept his severance of $\$ 11.6$ million from Washington Mutual, following only 18 days in office as CEO (Allison, 2008).

\footnotetext{
${ }^{13}$ Countrywide Financial was purchased by Bank of America in late 2008 (Hagerty, 2008); AIG experienced a significant decrease in share value in late 2008 because of financial market woes (Gomstyn, 2008); Washington Mutual was taken over by government regulators (Allison, 2008).
} 


\section{Analysis of High Profile Severances}

\section{Situations Requiring Paynent of Severance}

Severance pay is the general term used to denote both notice and severance, and is payable when an employer terminates a person's employment without cause, thereby breaking the employment contract (Torys LLP, 2007). Severance is not payable when an employee resigns or retires, as this involves an employee-initiated separation. Termination for cause, that is, employee wrongdoing, also does not result in a severance package. However, corporations wishing to terminate an employee for cause must prove gross incompetence or willful negligence, which is difficult to achieve (Minken \& Associates). As a result, most companies faced with a problematic employee would rather provide the employee with a severance package and avoid the hassle and effort required to fire an employee for cause; this is also true in the case of CEOs (Bebchuk \& Fried, 2006).

There are also times when an organization and an employee decide to agree that an employee will leave the firm. Rather than terminate the employee, the company permits the employee to resign. This situation could arise for any number of reasons. In these cases, a company may provide a severance, although the public message is that the employee has resigned or retired.

\section{Components of Severance Pay}

Severance pay is usually calculated as a number of weeks or months of pay that should be provided to the terminated employee (Torys LLP, 2007), and must compensate for the loss of "all non-discretionary compensation and benefits that the executive would have received had he or she continued to work during the notice period" (Torys LLP, 2007). 
Non-discretionary compensation and benefits include: base salary, benefits and incentive plans (Torys LLP, 2007). As a result, a severance calculation may be based on base salary, benefits continuation for the length of the notice period, pro-rated bonus earned during the year, and special treatment of stock options (Torys LLP, 2007; Paranzino). Often, stock options vest ${ }^{14}$ on termination, permitting the terminated executive to purchase stock that otherwise would have become available for purchase at a later date (Paranzino).

\section{Executive Severance Agreements}

In the case of executives, situations that would result in payment of severance are often defined in the CEO's employment contract (Torys LLP, 2007). These terms protect a newly hired CEO from risk of failure in the new position, which can happen for any number of reasons, such as a disagreement with the board about what direction the company should take.

\section{Introduction to Severance Analysis}

Considering the possible situational aspects mentioned above, it is sometimes difficult to determine the actual events surrounding the payment of a severance. In the examples below, effort will be made to identify the circumstances surrounding the CEO's departure. However, each situation is unique and the reader will notice that in some situations it was not possible to clearly determine what caused the departure, and whether a severance was validly payable.

Using the components of severance mentioned above, it may be possible to identify whether the media supplied figures accurately portray the severances provided to the eight CEOs listed, which must be ascertained prior to deeming any figure excessive. Proxy statements

\footnotetext{
${ }^{14}$ Vesting, in this case, means that the executive has full access to exercise the shares on as opposed to waiting for the exercise date to arrive, which would be the case if $s /$ he were still employed.
} 
covering each CEO's departure date were reviewed to determine the accuracy of media reported severances. The information obtained from the proxy statements is broken down in Exhibit 4 .

Each severance was assessed for excessiveness using an assumption that any severance over 2.99 times a CEO's annual cash compensation (salary and bonus) is excessive. To ensure that a calculation was not negatively impacted by a low bonus in the most recent year, three years of cash compensation were averaged and multiplied by 2.99 (shown in the last column of Exhibit 4).

Cxhit 4: CLO Severance Package Smmmaxy

\begin{tabular}{|c|c|c|c|c|c|c|c|}
\hline Company & Executive & $\begin{array}{l}\text { Proxy } \\
\text { Reported } \\
\text { Total }(\$)\end{array}$ & $\begin{array}{c}\text { Retirement } \\
{ }^{15}(\$)\end{array}$ & $\begin{array}{c}\text { Stock } \\
\text { Options/ } \\
\text { Awards }^{15}(\$)\end{array}$ & Misc. (\$) & $\begin{array}{l}\text { Severance } \\
(\$)\end{array}$ & $\begin{array}{c}\text { Avg. 3-year } \\
\text { Cash Comp. } \\
\quad \text { x } 2.99\end{array}$ \\
\hline 1. BCE Inc. & M. Sabia & $20,738,151$ & $1,253,000$ & $3,752,887$ & $6,141,064$ & $9,591,200$ & $3,239,167$ \\
\hline $\begin{array}{l}\text { 2. Manulife } \\
\text { Financial }\end{array}$ & D. D'Alessandro ${ }^{16}$ & & & & & & $17,245,782$ \\
\hline 3. Torstar & R. Prichard & $9,584,500$ & $2,018,000$ & $1,650,000$ & & $5,916,500$ & $4,442,044$ \\
\hline 4. Gillette & J. Kilts ${ }^{17}$ & & & & & & $11,147,717$ \\
\hline 5. ExxonMobil & L. Raymond & $351,182,311$ & $98,437,831$ & $252,744,480$ & & 0 & $19,678,685$ \\
\hline 6. KB Home & B. Karatz & $163,000,000$ & $27,847,225$ & $73,174,491$ & $61,978,284^{18}$ & & $18,026,046$ \\
\hline 7. Home Depot & R. Nardelli & $211,493,687$ & $33,467,795$ & $135,055,291$ & $3,500,000$ & $39,470,601$ & $23,336,375$ \\
\hline $\begin{array}{l}\text { 8. Merrill } \\
\text { Lynch }\end{array}$ & S. O'Neal & $161,500,000$ & $24,700,000$ & $131,400,000$ & $5,400,000^{19}$ & 0 & $34,584,333$ \\
\hline
\end{tabular}

Sources: (SEC's EDGAR database; BCE, 2009; CSA's SEDAR database)

It is important to note that this calculation is more generous than most non-executive employees receive. In Canada, current case law precedents indicate that non-executive employees can receive up to 24 months of severance (more, if punitive damages have been awarded), depending on individual situations (Torys LLP, 2007). Executives are typically

\footnotetext{
${ }^{15}$ This does not form part of severance.

${ }^{16}$ Manulife Financial's management information circular is not yet available. D'Alessandro departed May 2009.

${ }^{17}$ Gillette was subsequently purchased by P\&G. P\&G's proxy statement provided indistinct information about Kilts' severance.

${ }^{18}$ Variance unaccounted for in KB Home's proxy statement.

${ }^{19}$ Deferred compensation.
} 
awarded higher severance awards in recognition of their roles (Torys LLP, 2007). A limitation of using the 2.99 multiplier across the board is that it should be viewed as a maximum and not a standard formula to apply to each case, since it does not reflect differences in CEO tenure. For example, it would not be suitable to provide a CEO who had six months of tenure the same severance as a CEO who had been employed with a company for 40 years. However, since it is unknown what formula the corporations in the examples used to determine CEO severances, the 2.99 multiplier serves as the outer limits of what severance should have been paid.

\section{Severance Analysis}

\section{Example 1. Sabiar BCE Inc.}

Of the \$21 million stated in news reports about Michael Sabia's retirement from BCE in July 2008, \$9.6 million was severance. An additional \$1.253 million was paid as the company's 2008 pension contribution, $\$ 4.375$ million was paid for two bonuses, and the remainder, approximately $\$ 3.7$ million, pertained to stocks. Based on the reasonable severance calculation, Sabia was paid approximately $\$ 6.36$ million in excess severance as $\$ 9.6$ million was approximately triple the reasonable severance amount.

\section{Example 2: D'Alessandro, Manulife Financial}

D'Alessandro left Manulife Financial in May 2009. Due to the recency of this event, the applicable proxy statement is not yet available. However, D'Alessandro's reported \$12.6 million following 15 years with the company was not as high as this paper's calculated reasonable severance amount (\$17.2 million). As a result, it appears that D'Alessandro's severance was not excessive, especially considering that the media reported figure may include other amounts such as pension and stock awards. 


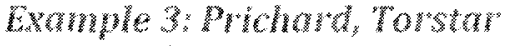

An analysis of Robert Prichard's reported \$9.58 million severance found that $\$ 5.9$ million was officially severance, and the rest consisted of pension and stock amounts. Using the reasonable severance calculation, it was determined that Prichard's severance was excessive by approximately $\$ 1.5$ million.

\section{Example 4: Kilts, cillete}

Kilts' reported severance amount was $\$ 165$ million. Because the company was acquired by Procter \& Gamble in 2005 and Kilts retired in October 2006, it is difficult to ascertain from filings what the $\$ 165$ million comprised since Kilts continued to earn compensation following the acquisition. There is, however, a substantial variance ( $\$ 154.85$ million) between a "reasonable" severance of $\$ 11.15$ million and the $\$ 165$ million amount Kilts reportedly received.

The Kilts is the sole example in the list of a change in control severance resulting from a merger or acquisition and demonstrates the difficulty in analyzing this type of severance situation.

\section{Example 5: Raymond, ExxonMobil}

In the ExxonMobil example involving Lee Raymond's 2005 departure, scrutiny of the 2006 proxy statement clarifies that Raymond did not receive a severance on leaving the firm. The reported figure comprised only the value of the retirement package and stock awards/options he had amassed over his 42-year career with the company. Because a severance is not payable in all situations, there is no reason to believe that Raymond was owed a severance. The value of his pension upon leaving the firm was over $\$ 98$ million, which seems excessive. Assuming he lived 
another 25 years after retirement, that would mean he would have to spend $\$ 4$ million plus interest earned per year to consume his pension.

The stock options and awards figure of over $\$ 252$ million also appears excessive, although it was accumulated over the length of his career. That would mean Raymond earned on average $\$ 6$ million in shares each year of his 42 -year career with Exxon. In reality, he probably earned the shares during the latter part of his career, so his recent annual stock awards were probably closer to $\$ 10$ million per year or higher.

\section{Exmmle 6: Karatz, KB Home}

Details reported in KB Home's 2007 proxy filing does not provide a clear picture of Karatz's exit package and it was impossible to determine whether the actual severance amount was excessive.

Since Karatz's pension and stock options/awards are accounted for, it is possible that the remaining $\$ 62$ million is severance. It is also possible that none of the $\$ 62$ million was severance; it could have been outstanding bonuses and other payments. The proxy statement specifically stated that the nature of the separation would not be defined (i.e. termination or resignation) and that payments were not being made pending resolution of the issues, leaving this analysis without sufficient information to break out the remaining details of the $\$ 163$ million reported in the media.

The lack of clarity surrounding Karatz's severance is in large part due to a court order and agreement with the company prohibiting Karatz from receiving some of his termination benefits (SEC's EDGAR database). In the court order, Karatz was prohibited from exercising 
some stock options because of concerns that he had manipulated the exercise date (Herbst, 2006). This is an important point, as it represents an example of the principal-agent problem.

Regardless, returning to the issue of the package's excessiveness, the unexplained $\$ 62$ million appears excessive in comparison to a "reasonable" severance figure. The $\$ 73$ million in stock options/awards and the $\$ 28$ million pension also appear excessive.

\section{Example 7: Nardell, Home Depot}

According to Home Depot's 2007 proxy statement, only \$20 million of Nardelli's \$211.5 million severance was actually identified as severance. Arguably up to $\$ 42,970,601$ could be classified as severance, as $\$ 18$ million was provided in consideration for non-compete and non-solicitation agreements, $\$ 1.4$ million was provided to cover legal fees and health insurance benefits (Home Depot, 2007), all of which are items typically covered in a severance package. (Another $\$ 3.5$ million was provided for a foregone bonus and outstanding dividends, which are not, strictly speaking, severance items.)

As with Karatz, the bulk of the package pertained to stock awards and stock options (approximately $\$ 135$ million) none of which was granted due to his departure, and $\$ 33,467,795$ pertained to the cashing out of his Supplemental Executive Retirement Plan (SERP), which was also not granted in conjunction with his departure. Although the media had reported the severance as $\$ 210$ million, the proxy statement clarifies that only approximately $\$ 39.5$ million of Nardelli's "severance package" can strictly be classified as such. A comparison of this figure to this paper's standard indicates that Nardelli's severance was excessive in the amount of $\$ 19.3$ million, based on a comparison of the two highlighted columns in Exhibit 4. 
Similar to Lee Raymond, Stanley O'Neal did not receive a severance from his company upon his departure. The "exit-pay package" referred to in the media (Moran \& Yap, 2007) included only the value of O'Neal's pension and stock awards accumulated over the length of his service with the company. Again, the most glaring figure is the $\$ 131.4$ million in stock and stock options Raymond had acquired during the course of his employment.

\section{Summary}

This analysis produced three significant observations. The first observation is that the media had inflated the severance information by incorporating pension benefits and stocks/options that had been accumulated over the CEO's corporate career, resulting in higher reported severance numbers than the facts bore out. In addition, in two of the cases, Raymond and O'Neal, the media reported figures contained no severance at all, so the media reports grossly exaggerated or misled the public about the nature of the figures they presented.

The second observation is that three of the eight severances were clearly excessive according to this paper's benchmark, and an additional two were potentially cases of excessive severance, although the information was not clear enough to provide a definitive answer. Another example was deemed not excessive (D'Alessandro).

A third observation, in looking at the total number reported by the media, is that the bulk of the money in the U.S. examples pertained to stock options and stock awards, and it appears that the core area of excess is the granting of executive stock and stock options over the course of an executive's career with a company. 
In summary, from a purely severance perspective, at least $37.5 \%$ of the examples were excessive, ranging up to a possible $62.5 \%$ of cases. A closer look at the three cases involving excessive compensation showed that actual severances ranged from $133 \%$ to $296 \%$ of reasonable severance figures, confirming that companies are not limiting their severance practices to 2.99 annual salary and bonus, and that shareholders understandably have reason to complain. The analysis also showed that shareholders have reason to complain about the volume of stock and stock options granted to executives during the course of their careers, as the wealth accumulated through this vehicle appears excessive.

Treatment of other employees differs substantially from the treatment of CEOs cited above. Human Resources departments of large, publicly traded companies use well-defined salary grading or banding structures that ensure that employee wages are maintained within a defined range, to ensure that employees of different levels (contributor, supervisor, manager) and expertise (administrator, creator or negotiator) are rewarded accordingly and that an appropriate distance exists between the salaries so that a sense of fairness presides (Astron Solutions LLC, 2007). Furthermore, annual wage increase guidelines in recent years have ranged from $2 \%$ to $4 \%$ of base salary (Culpepper, 2008; Cohen K. , 2006) while growth in CEO pay grew exponentially as demonstrated earlier in Exhibit 2.

Severances for these levels of employees are determined using either a company's severance policy or by virtue of common law, which currently dictates that approximately one month's base wages per year of service are payable to a terminated employee ${ }^{20}$ (Hassell, Hanson,

\footnotetext{
${ }^{20}$ The specifics of each case (age, service, level in the organization, jurisdiction) play a role in determining a severance amount, but this is by no means an exact science.
} 
\& Meyer, 2008). These salary and severance structures ensure that payroll costs are maintained within tight limits.

My observations surrounding the divergent treatment of CEOs and employees lie in the nature of their location and position in the firm's hierarchy. For employees, budget restrictions and salary structures apply; other layers exist above them; they are only one of many; they can be easily replaced if they are unhappy with their income; and they do not have sufficient influence over decision makers to dictate their own salaries. The opposite appears to be true for CEOs: budgetary restrictions do not seem to apply; salary structures do not exist; no higher corporate layers depress their salaries; they are one of a kind within the firm; their skills are not as abundantly available in the general population so they may not be easily replaced; and they may have influence over their own salaries as they are in direct contact with decision makers (directors). CEO influence over those determining their wages were discussed in greater detail in the "Challenges" section of this paper. 


\section{Shareholder Discontent and Activism}

Shareholders have become more interested in and involved with corporate governance of publicly traded corporations, especially surrounding matters of executive compensation and executive severance, and justifiably so based on the examples provided above. Moral outrage drives some of their interest. A 2004 article in Electronic Business discusses the growing number of shareholder resolutions, and attributes the growth to shareholders' wishes to publicize issues and force companies to become more socially responsible with respect to executive pay (Roberts, Shareholders take aim at executive pay, 2004).

Shareholders also feel that executive severances do nothing but appropriate corporate funds and diminish shareholder wealth (SEC's EDGAR database). Cases such as Lehman Brothers (Ross \& Gomstyn, 2008) have demonstrated that the diversion of capital from business needs to employees' bank accounts can decimate a company's viability.

The overarching objective of shareholder involvement is to protect shareholder wealth, which can be negatively impacted by a number of company and board actions, including: strategic direction, operating results, company's stance on corporate social responsibility (CSR), failure of the board to ensure management performance and accountability for corporate results, failure to comply with legislative requirements, and executive compensation (Canadian Coalition for Good Governance, 2005). Failures in any of these areas can reduce shareholder wealth through stock dilution, long-term viability of the corporation, and reduced stock price (through lower than expected operating results, reduced confidence in the company, or diminished desire to purchase the company's product due to poor CSR reputation). 
Recall from the review of the CBCA, the DGCL and OSC/SEC regulations (in the earlier section entitled "Legislative Framework") that directors and officers have no direct accountability to shareholders beyond carrying out their fiduciary duty and duty of care. So what recourse do shareholders have to increase board and officer accountability to keep CEO severances in check? Alternatives can be classified into two categories: legal routes and unofficial routes.

\section{Legal Shareholder Alternatives}

On a legal front, shareholders can pursue a number of alternatives in an attempt to force corporate boards to comply with their wishes. In increasing order of cost and effort, they are:

1. Submit shareholder resolutions proposing shareholder pre-approval of CEO employment contracts, including severance arrangements and change in control clauses.

2. Remove one, several or all directors from the board through a shareholder vote, if directors are unresponsive to shareholder concerns.

3. Sue the directors and/or the corporation for failing to protect shareholder interests.

Submit shareholder resolutions proposing shareholder preapproval of CEO employment contracts, including severance arrangements and change in control clatses.

A commonly used approach employed by shareholders is to submit a resolution calling for a shareholder vote at the company's annual general meeting. More and more, shareholders are using this avenue to voice their concerns about corporate governance issues, including executive compensation. This approach is easy to pursue because individual shareholders can propose resolutions for vote at the $\mathrm{AGM}$ and this option does not require rallying other shareholders to 
your point of view. This alternative is beneficial if the objective of the resolution is to raise visibility of the issue without necessarily wanting to ensure passage of the resolution.

An objective of resolution passage, however, would necessitate a shareholder to convince other shareholders to participate in the vote and approve the resolution. Regardless of whether a resolution passes, it becomes part of a permanent and visible public record that may cause boards to pay attention to the issues raised (Roberts, Shareholders take aim at executive pay, 2004).

\section{Exhibit 5: 10-Year Growth in Number of Shareholder Resolutions}

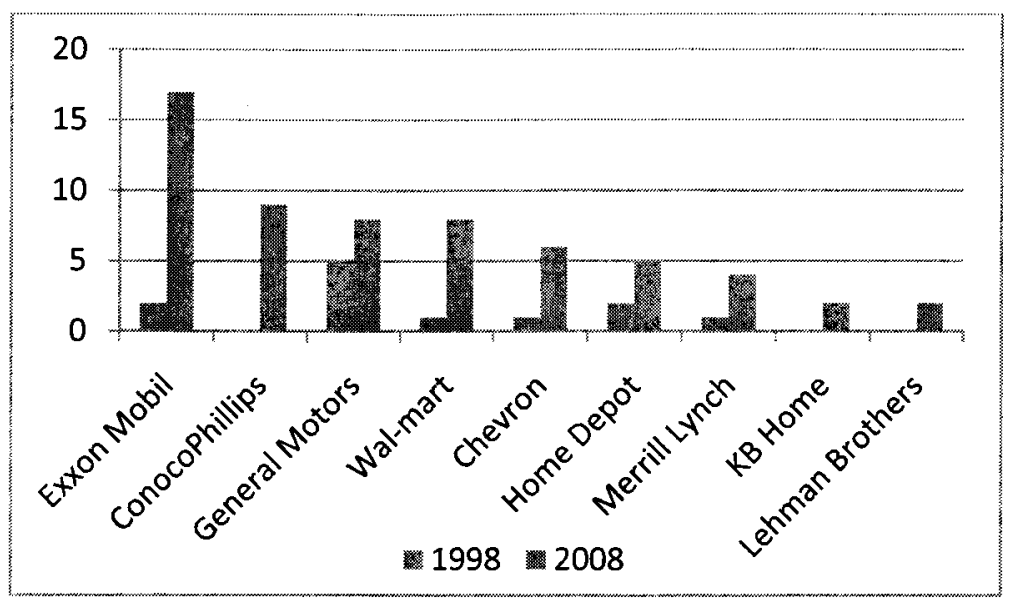

Sources $^{21}{ }^{22}:$ (SEC's EDGAR database)

Exhibit 5 shows a snapshot of the increase in shareholder-presented resolutions over the last ten years, $1998-2008$, for a selection of firms. The companies included are five of the top ten in the U.S. Fortune 500 and four of the companies mentioned above that have provided large severances to departing CEOs. ExxonMobil falls into both categories. On average, the number of shareholder resolutions increased by 500\% during this time, demonstrating shareholders' dissatisfaction with board activities and increased concern over corporate governance matters.

\footnotetext{
${ }^{21}$ Gillette's 2005 proxy statement is used, since the company was absorbed by Procter \& Gamble in 2005.

${ }^{22}$ ConocoPhillips' earliest available proxy statement, dated April 4, 2003, was used.
} 
Increasingly, the subject of shareholder resolutions is the restriction of executive compensation. Research conducted by the Investor Responsibility Research Center (IRRC) in 2003 found that the number of shareholder proposals regarding executive compensation increased by $200 \%$ over the prior year (332 versus 106) (Roberts, Shareholders take aim at executive pay, 2004). The majority of the resolutions pertained to executive golden parachutes and the pay disparity between regular employees and executives (Roberts, Shareholders take aim at executive pay, 2004).

The increase in shareholder activity at BCE Inc. following Sabia's retirement demonstrates the extent to which shareholders are increasingly requesting a greater say on and more thorough disclosure of executive compensation. At the next year's AGM, BCE's shareholders submitted a substantial number of shareholder resolutions on these topics, including:

- That the ratio between BCE's top paid executive and lowest paid employee be calculated and included in the proxy circular for shareholder information, stating that executive compensation was "far too generous" and "unfair" to other employees (CSA's SEDAR database),

- That shareholders be required to "pre-approve" the compensation paid to the companies five highest-paid executives, and to approve directors' compensation, stating that the compensation structure was "excessive" (CSA's SEDAR database),

- That executives and directors not be permitted to exercise stock options during their tenure, proposing that incumbents could only exercise options after having left their $\mathrm{BCE}$ roles, citing "eroded shareholder wealth" as the issue (CSA's SEDAR database), 
- That total compensation, including base salary, bonus and stock/options for executive and director compensation be limited to $\$ 500,000$ in 2009 and 2010 (CSA's SEDAR database),

- That the CEO not be involved in the selection of the company's independent compensation committee and that executives be excluded from any discussions on executive compensation. This resolution was proposed to address their concern that the executive compensation process was potentially being skewed by the participation of the compensation recipient(s) (CSA's SEDAR database).

- Finally, shareholders proposed that BCE's executive compensation policy be subject to a shareholder advisory vote. Shareholders cited a survey of 280 Canadian companies by McKinsey, HRI Corporation and the Canadian Coalition for Good Governance, which found that, in general, $40 \%$ of board members and $65 \%$ of shareholders of publicly traded companies felt that executives were overpaid (Good Goverance Guidelines for Principled Executive Compensation, 2006). The resolution also made reference to statistics indicating that $40.3 \%$ of Canadian bank shareholders had approved such a resolution, and proposed that $\mathrm{BCE}$ should approve the resolution, claiming that legislative bodies might soon enforce such a requirement (CSA's SEDAR database).

The foregoing demonstrates the extent to which shareholder attention has been focused on this issue; none of these resolutions had been proposed at BCE's AGMs in the two years prior to Sabia's departure. Furthermore, an examination of Canadian proxy circulars and SEC proxy statements identified that corporate directors predominantly advise shareholders to vote against shareholder proposals, regardless of the companies and issues involved. Of the nine shareholder resolutions presented at BCE's two latest AGMs, directors recommended that shareholders reject 
eight of the proposals. The proposal concerning a non-binding advisory vote was recommended for approval by the directors (CSA's SEDAR database).

In some cases, the same resolution is presented by individual shareholders or shareholder groups year after year in the hopes that the message will finally be received by corporate boards. For example, Pfizer's shareholders presented the same resolution in 2005, 2006 and 2008 calling for the separation of the CEO and Chair roles (SEC's EDGAR database), in order to lessen the power of the CEO to set his own compensation. Although voting resulted in $40 \%$ approval in 2005 , subsequent votes failed to achieve the majority necessary for the resolution to be carried (SEC's EDGAR database).

In another example, a shareholder of ExxonMobil (Ram Trust Services) presented the same resolution regarding the separation of CEO and Chair roles in three consecutive years (2006 - 2008), with the same objective (SEC's EDGAR database). More pertinently, another ExxonMobil shareholder (NorthStar Asset Management) submitted successive proposals in 2006 -2008 requesting that the company re-evaluate its executive compensation practices after learning that CEO Lee Raymond's compensation was $\$ 80$ million in 2004, $\$ 70$ million in 2005, and that the company's new CEO, Rex Tillerson's, 2006 compensation was over $\$ 13$ million (much reduced, but still substantial) (SEC's EDGAR database). In the resolution, NorthStar pointed out that the salaries of ExxonMobil grossly exceeded CEO compensation paid to the company's competitors Chevron (by four times) and Conoco (by double) (SEC's EDGAR database). 
The extent of shareholder outrage became unmistakable the year following Raymond's

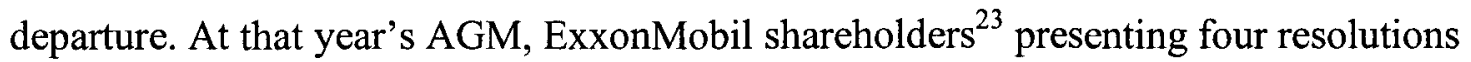
proposing advisory shareholder voting and limits on executive compensation (SEC's EDGAR database) in order to prevent a reoccurrence of compensation excesses with the new CEO. Directors recommended voting against all of these shareholder resolutions, stating that "executive compensation ... is competitive with market practices" (SEC's EDGAR database).

The board's stance against these shareholder proposals appears contradictory to their role as representatives of shareholder interests. It is difficult to understand why boards would reject an opportunity to receive shareholder input, especially "advisory" input that the board is not required to act upon in any event. Many people would likely agree that boards, in their capacity as representatives of shareholder interests, should be interested in receiving shareholders' thoughts through all possible communication methods and supporting the issues that shareholders raise. These types of examples seem to indicate that boards are not interested in understanding shareholder views.

Unfortunately, information regarding the results of shareholder resolutions is not published, although the impact of approved votes may be visible in future proxy disclosures (through additional information provided, or through director submitted resolutions for shareholder vote). Regardless, the growing number of shareholder resolutions pertaining to CEO compensation, whether successful or unsuccessful, may cause corporate boards to thoroughly consider compensation decisions before acting, knowing they will be subject to SEC disclosure regulations and shareholder (and public) scrutiny (Herbst, 2006).

\footnotetext{
${ }^{23}$ One of these shareholders was Lucien Bebchuk, co-author of Pay without Performance (SEC's EDGAR database) and well-known authority on the subject of executive compensation.
} 


\section{Effertweness of Alvisory Shareholder lates}

A study in the United Kingdom, where advisory shareholder votes on executive compensation have been law since 2002, investigated whether advisory votes impacted director decisions on CEO compensation in the area of salary, bonuses and stock-based pay (stocks) (Carter \& Zamora, 2009).

The study, conducted on U.K. companies between 2002 and 2006, found that advisory shareholder votes did cause directors to provide lower compensation to CEOs as a result of negative shareholder votes, especially with respect to equity pay, and especially when a high number of shareholders felt that the compensation level being proposed was too high (Carter \& Zamora, 2009). The study also found that shareholders voted against bonus schemes that did not effectively incentivize performance (Carter \& Zamora, 2009). This study demonstrates that, although directors still have the option to ignore results of advisory votes, such votes can have the effect of curbing growing executive compensation, making pursuit of this right a worthwhile endeavor for shareholder groups.

Remove one, several, or all directors from the board though a shaveholder vote.

Another shareholder option is to remove directors from the board. Shareholders can remove some or all directors if they disagree with the direction the board is setting for the company. Success at removing one or more directors from the board is difficult to achieve, as shareholders must be rallied and band together in advance of a vote in order to ensure that their action will be successful.

Research undertaken as part of this paper to determine whether shareholders have been successful at removing directors from boards found that shareholders have achieved this result in 
a number of cases. In May 2009 shareholders of Amylin Pharmaceuticals Inc. removed Chairman Joseph Cook from the company's board and filled his and another vacancy with directors proposed by shareholders (Olmos, 2009) because they felt that Cook had underrepresented the company in its contract with Eli Lilly \& Co over Byetta (a diabetes medication), which was detrimental to shareholder wealth maximization.

In another case, majority shareholders of Take Two Interactive Software (makers of video games such as "Grand Theft Auto") voted out five of the company's six directors, including the CEO, and replaced them with their own nominees, because majority shareholders felt that the board was ineffective at running the company (Konrad, 2007). Research did not uncover cases in which board members were removed due to disputes over executive compensation or severance.

Shareholders face some challenges in attempting to vote directors off boards. According to RiskMetrics ${ }^{24}$, more than $50 \%$ of TSX-listed companies still employ a "slate" approach to director elections (RiskMetrics Group, 2008). This means that directors are bundled and shareholders are required to vote for all or none (RiskMetrics Group, 2008). As a result, unless shareholders wish to remove all directors from the board, they will necessarily vote in favour of their (re)election or may abstain from voting.

Sue the directors and/or the corporation for follhy to protect shareholder interests.

A third legal shareholder remedy is to sue the company and/or its directors for failure to perform their fiduciary duties. This is an expensive alternative as it requires shareholders to incur the

\footnotetext{
${ }^{24}$ RiskMetrics is a global organization that encourages "transparency and access for all market participants" (About RiskMetrics Group).
} 
expense of lawyers to present their case in court although it may be possible to recoup the outlay if the court awards the plaintiff court costs (if the court rules in favour of the plaintiffs).

Shareholders in Manitoba applied this approach when they sued Protos International for having used the company as "their personal bank accounts" (Kirbyson \& Lett, 2007). Employing the "shareholder oppression remedy", shareholders successfully sued the directors and officers of the company to recover corporate funds appropriated by them for their personal expenses (Kirbyson \& Lett, 2007). The oppression remedy permits shareholders to sue an incorporated business "where conduct has occurred which is oppressive, unfairly prejudicial or which unfairly disregards the interests of a shareholder, creditor, director or officer" (Industry Canada, 2005).

In a U.S. case, this tack was also taken by Disney shareholders when Michael Ovitz was terminated after only 14 months as President and given a reported $\$ 140$ million severance package. Shareholders charged that Disney's directors had "waste[d] ... corporate assets" by permitting a large severance package to be written into Ovitz's employment contract (Nordick, 2006). In its 2006 ruling, Delaware's Court of Chancery stated that the business judgment rule would apply. The business judgment rule states that, provided that directors and officers carry out their fiduciary duty and duty of care, the courts will not second-guess their decisions (Nordick, 2006). The ruling meant that, despite a number of inconsistencies in board procedures at Disney (that CEO Eisner had not involved the board in Ovitz's hire, employment contract or termination) (Nordick, 2006), the court would not interfere with the board's decision on Ovitz's severance package, supporting the legislatively provided rights of directors to manage the corporation and its affairs. 
The Delaware Chancery Court also ruled that it would only find in favour of such a case if it found "intentional dereliction of duty" (Nordick, 2006; Kamlet Reichert Legal Updates, 2005), thus protecting directors from most future claims of failure to meet fiduciary duties and duties of care. As a result, directors can fail to ask for information, as they did in this case, and remain free from legal prosecution, since the court viewed as "best practices" what many people would consider proper board diligence. The judgment was appealed to the Delaware Supreme Court. This case has not yet been heard.

This ruling demonstrates that shareholders will have to prove a high standard of "bad faith" behavior in order to pursue legal action against directors for a failure to fulfill their fiduciary duty, at least in the United States, until the appeal is heard.

\section{Unofficial Shareholder Alternatives}

In addition to legal remedies, shareholders have some unofficial alternatives to increase board interest in listening to shareholders views. Two alternatives include:

1. Raising issues in the media to draw public attention and generate public outrage.

2. Initiating direct, unofficial discussion with board members.

\section{Raise issues in the media to draw public attention to generate public outrage.}

One option is to attract the media's and the public's attention to the issue, as the AFL-CIO has done through media-covered public protests (Herbst, 2006; Nardelli's "Severance", 2007). To further draw attention to this issue, the AFL-CIO maintains a website devoted to the issue of excessive pay where it compiles, lists and ranks compensation paid to the United States' highest paid executives, and compares it to the pay of average workers. This alternative can be successful in generating outrage, but public support can be short-lived, and the public may not 
have the expertise to understand the scope of the problem and how it affects them (through increased product prices, for example).

\section{Initate direct, unofficint discussion wh theard nembers.}

This approach is gaining popularity as some boards have become more open to discussing corporate governance and executive compensation issues with shareholders. RiskMetrics, a global risk management research organization, recently conducted a study of six publicly traded corporations, including Home Depot, McDonald's, Bristol-Myers Squibb, and Occidental

Petroleum (Deane, 2009). The study found that boards became more receptive to discussion with shareholders when such gatherings followed a corporate scandal or controversy (Deane, 2009). The study also found that the meetings were beneficial in building relations between the two groups, and gave directors more confidence to address shareholders at upcoming formal meetings (Deane, 2009). In its "Key Agreed Principles", the National Association of Corporate Directors (NACD) in the U.S. agrees that boards should "consider reaching out and developing stronger relationships with investors through candid and open dialogue" (National Association of Corporate Directors, 2009).

\section{Summary}

Some opponents of increased shareholder input and participation believe that shareholders are temporary investors that hold their investments from seven to fifteen months before selling and moving on to more lucrative investments (Pruijm). These opponents believe that investors are interested only in short-term returns and therefore should have little influence over a company and its board (Pruijm). This view, however, does not appear to be correct, since shareholders are accusing companies of pursuing short-term objectives to the detriment of long-term growth. If 
shareholders were fleeting participants in the voting process, they would not make this claim. Furthermore, voting restrictions require shareholders to hold shares for a minimum period (at least one year) before they are authorized to participate in the voting process, which pre-empts short-term investors from participation.

Shareholders have a number of formal and informal approaches available to them to influence board behavior or, in extreme cases, remove directors from the board. Many of these are time-consuming and tedious, and blocked by board practices such as slate ballots. Time and again some boards have demonstrated that they do not care to listen to shareholders, and do not concur with issues raised in shareholder resolutions, as evidenced by directors' recommendations to vote against shareholder submitted resolutions in proxy statements. Examples of these include BCE Inc, Pfizer and ExxonMobil, as mentioned in the "Legal Shareholder Alternatives" section above. Other boards have become more open to listening to the concerns of shareholders and have opened themselves up to meeting informally with shareholders to understand their concerns, as RiskMetrics found in its study of six publicly traded companies (Deane, 2009).

The final option for shareholders is to invest elsewhere. While there are still many shareholders willing to invest in uncooperative corporations, many shareholders are pushing for increased shareholder involvement in decision making.

Currently shareholders receive valuable information through the proxy statement that educates them on board and management activities. If shareholders learn information that indicates that the board has implemented an undesirable policy that would negatively affect the share price once implemented, such as a change in control arrangement that would provide an executive with a large payment on a single trigger, they can sell their shares. An en-masse sell- 
off by disgruntled shareholders following the release of a proxy statement would depress the stock price and send a strong signal to the board that the arrangement is unacceptable. Unfortunately, shareholders receive valuable compensation related information too late to influence it, in a form of informational injustice (Harris, What's Wrong with Executive Compensation?, 2009), and few board policies permit shareholders to provide feedback before an action is taken. These shareholders may eventually find profitable, ethical corporations to invest in that also listen to shareholder input, potentially resulting in a future where fewer shareholders will be willing to invest in corporations with deaf corporate boards. 


\section{Change in Control}

The phrase "golden parachute" is the term that has been applied to a type of severance relating to a change in control. "Change in control" applies to a situation in which there is a change in the majority shareholder of the company, usually as the result of a merger or acquisition (Thornton, 2005). This situation presents a unique challenge to a CEO; when a larger company acquires another, it may wish to replace the acquired company's CEO, replacing him or her with someone of their own choosing, although this is not always the result (Thornton, 2005). Because of this risk, a CEO may focus on his or her own situation rather than focusing on what's best for shareholders in the period leading up to and during the transition (Thornton, 2005). The purpose of a golden parachute arrangement is to focus a CEO's attention and efforts on achieving the best possible result for shareholders (Thornton, 2005).

The 1982 case of William Agee of Bendix mentioned in an earlier section entitled "Growth in CEO Salaries and Severances" above is one of the notable early cases of a change in control severance. In this case, Agee initiated an acquisition that eventually resulted in his company, Bendix, being acquired by a third company (Allied Corp.), during which Agee left the company with a $\$ 4$ million ownership change related severance. This caused outrage and resulted in U.S. legislators passing a law that applied an excise tax on any severance that was greater than 2.99 times salary and bonus (Thornton, 2005).

By 2001 , of the one thousand largest companies in the U.S, $81 \%$ had change in control arrangements, as a proactive measure should a takeover or merger arise (Thornton, 2005). A 2007 Mercer survey found that most change in control arrangements were comprised of three basic clauses: 1) they paid out only upon the triggering of two events (takeover and job loss), 2) 
they protected an executive from a change in control related termination up to two years after the event, and 3) severance was paid out in cash at three times annual base salary and incentive (Mercer, 2007).

Some change in control arrangements abuse their intended purpose. For example, Mercer's survey found that some companies' change in control programs paid out upon the occurrence of a single trigger (acquisition) and did not require the executive to lose his or her job before payment was initiated (Mercer, 2007). Some policies also permitted payment if the executive resigned (not including constructive dismissal). These situations can result in a windfall to an executive that does not enhance shareholder value (Thornton, 2005) and does not meet the objective of a change in control arrangement. Other cases include companies whose change in control arrangements are triggered if as few as $20 \%$ of shares change ownership (Thornton, 2005).

The fact that some companies have seen fit to provide golden parachute payments even though situations do not warrant them has resulted in increased shareholder attention. According to 2005 and 2006 Watson Wyatt studies, $64 \%$ of institutional investors feel that "change in control agreements for top executives are shareholder unfriendly" (Kay \& Seelig, 2007). Both Mercer and Watson Wyatt believe there is a place for change in control arrangements in corporation policy, provided the terms are carefully designed. The section below, "Best Practices" outlines how change in control arrangements can be configured to avoid payment triggers that do not enhance shareholder value. 


\section{Director and CEO Response}

A study by Lawler and Finegold of director and CEO perceptions of CEO compensation found that only $9 \%$ of CEOs and $38 \%$ of directors felt that CEO compensation was too high (Lawler III \& Finegold, 2007). A high proportion (91\%) of CEOs felt that their compensation was "about right" or generally in-line" (Lawler III \& Finegold, 2007). In contrast, a majority of directors, $62 \%$, felt that CEO compensation was "about right" or "generally in-line", with a slightly smaller number of independent directors (59\%) feeling the same way (Lawler III \& Finegold, 2007). Neither group felt that CEO compensation was too low (Lawler III \& Finegold, 2007).

These statistics demonstrate that directors and CEOs acknowledge on the one hand that no cases of inadequate CEO compensation exist. On the other hand, there is substantial perception that CEO compensation is appropriate, although almost $40 \%$ of directors felt that CEO compensation was too high (Lawler III \& Finegold, 2007). In addition, there was a substantial disconnect between the perceptions of CEOs and directors, with significantly more CEOs considering CEO compensation appropriate. Directors also felt they should spend more time on executive compensation (71\%), indicating they felt the matter required further attention (Lawler III \& Finegold, 2007).

Business Roundtable is a large organization of U.S. corporate CEOs. Among others, Business Roundtable's objectives include encouraging high ethical standards and integrity in corporate activities and transparency in corporate operations (Corporate Leadership; Corporate Governance). As a result of growing concerns and disagreement surrounding executive compensation, the organization has issued its own statement of "executive compensation principles" to guide companies on "responsible and transparent" (Business Roundtable, 2007) 
compensation practices in this challenging area. Their seven principles are as follows (Business Roundtable, 2007):

1. Executive compensation should be aligned with long-term shareholder interests. Ensure that significant upside and downside potential exists in "at risk" compensation, and ensure that payment is not made if business results so warrant.

2. The level and composition of CEO compensation should be determined by independent directors.

3. The Compensation Committee must be well qualified and understand fully all aspects of CEO compensation, and should fully evaluate what payments result under all types of scenarios (retirement, severance). Boards should ensure that CEOs terminated as a result of a failure to achieve business objectives do not receive excessive severance packages, and ensure that the consequences of "for cause" terminations are clear.

4. Executives should be required to invest a significant level of equity in the company.

5. The Compensation Committee should avail itself of independent consultants that do not have any conflicts of interest.

6. The Compensation Committee should ensure that the compensation complies with laws and conforms to best practices.

7. Corporations should fully disclose all elements of executive compensation to shareholders.

These principles indicate that executive acknowledge that improvements can be made to current compensation practices and tie closely with many of those recommended by advisory and advocacy groups, which will now be discussed. 


\section{Best Practices}

The issues surrounding corporate governance have resulted in the establishment of a number of advocacy and advisory organizations, both in Canada and the U.S. Some have as their mandate to advise, educate and advocate for shareholder rights, and others provide guidance to directors on matters of effective and ethical corporate governance. In Canada, two groups also provide education and certification of directors so that they are better qualified to carry out their duties on corporate boards.

Almost all of the websites of these various advisory groups contain a link to a section pertaining to executive compensation, which indicates how contentious the issue of CEO pay has become, and that further decisive action is required. Some shareholder advocacy groups, such as United for a Fair Economy in the U.S. and Quebec's Mouvement d'éducation et de defense des actionnaires annually determine what "burning issues" they plan to pursue with publicly traded companies. This section will discuss some of the best practices for executive compensation advocated by the various groups.

\section{Performance Pay}

Recommended practices include having a large portion of an executive's pay tied to achievement of operational or other corporate results. It is recommended that $25 \%$ to $50 \%$ of an executive's wealth should be "at risk" to performance objectives, and no incentive payment should be made if objectives are not met (Bisson, 2009).

The Canadian Coalition for Good Governance, which represents institutional investors, believes that subjecting a significant portion of an executive's pay to risk and ensuring that an executive is appropriately measured against results achieved are necessary to an appropriate 
executive pay structure (Canadian Coalition for Good Governance, 2009). Achievement of this objective requires that boards stand firm and not make exceptions by providing an incentive or bonus payment when results are not achieved.

\section{Equiry Stakes}

Advocacy groups recommend that a significant portion of an executive's total wealth be invested in company shares, the same view as stated earlier by David Bisson of Presidio Pay Advisors.

The Canadian Coalition for Good Governance also recommends that boards look at stock options granted over an executive's entire career prior to granting further options, to ensure that compensation is competitive yet contained, and represents an appropriate amount of equity to motivate the executive (Canadian Coalition for Good Governance, 2009). Re-pricing of "underwater" shares (those that can be exercised at a higher than market rate) should not be performed (Canadian Coalition for Good Governance, 2009). The Canadian Center for Good Governance believes that both down-side and up-side potential should exist in the stock-based compensation format to ensure that executive performance is partially driven by down-side risk avoidance (Canadian Coalition for Good Governance, 2009).

I foresee some issues with this approach. Currently, companies design a CEO's equity position not as a portion of his or her wealth, but rather as it relates to base salary, as the objective has been to implement an appropriate split between base compensation and compensation that is "at risk" (Bisson, 2009). Ensuring that $25-50 \%$ of an executive's total wealth is "at risk" would require an executive to disclose this value to the company, which s/he is not likely to divulge, or could manipulate to his or her benefit (i.e. to increase the company's 
compensation offering). A second challenge is that, if an executive has held successive high level positions in different companies that subscribed to this view, each company would be required to provide greater and greater stock and options to meet the $25 \%$ to $50 \%$ "at risk" requirement, thereby driving up that executive's compensation and, as a result, comparative compensation used by the rest of the industry, which would influence other CEOs' compensation levels. So, while this approach, in conjunction with specific, measurable performance objectives, would be beneficial, it may have the unintended consequence of driving executive compensation to even higher levels.

\section{Termination Pay, including Change in Control Provisions}

Companies should have written contracts with executives that provide for an amount similar to that which would be granted under common law (not more) (Canadian Coalition for Good Governance, 2009). Where an executive has failed to perform, companies should provide no severance pay and ensure that the executive understands that this potential situation can result (Canadian Coalition for Good Governance, 2009).

With respect to change in control, a severance payment should only be paid when two triggers occur: 1) an actual change in control has occurred, and 2) the executive has been terminated or constructively terminated within a defined period following the change (Canadian Coalition for Good Governance, 2009). A change in control means that a new party has become the majority shareholder (Canadian Coalition for Good Governance, 2009), with the ability to influence the future direction of the company, thereby posing a risk for the continued employment of the acquired company's CEO. No payment should be made if an executive resigns, unless constructively dismissed (Mercer, 2007). Compensation Committees should 
review these policies regularly, and always upon any change in compensation that could result in a greater payment (Mercer, 2007).

\section{Retwement Plans}

In Canada, employees earning over a certain wage are disadvantaged due to the governmentimposed wage limits on pension plans (Cohen \& Fitzgerald, 2002). To compensate for this shortfall, an executive may be provided with a supplement executive retirement plan (SERP). The Canadian Coalition for Good Governance recommends that boards set limits on the amount of additional income replacement a SERP will provide, and not to provide an incoming executive with recognition for "years worked" (i.e. at another company) (Canadian Coalition for Good Governance, 2009). 


\section{Regulatory Responses}

This paper has demonstrated the close linkage between executive compensation and effective governance practices, including the need for independent directors and the separation of CEO and Chair roles. A number of targeted regulatory responses pertaining to the complex matter of executive compensation in publicly traded companies have occurred in the past while, partially resulting from increased shareholder activities, but predominantly initiated by the economic crisis that occurred in late 2008 as the result of sub-prime mortgage lending.

Canada's Securities Administrators and the U.S. Securities Exchange Commission work closely to ensure a level of consistency between stock exchange policies and practices in the two countries. The United States tends to take the lead in developing new standards and regulations, which, many times, are adopted by Canadian securities regulators ${ }^{25}$ (Schedule Announced for Completion of U.S.-Canadian Mutual Recognition Process Agreement, 2008). In this section, recent Canadian and U.S. regulatory initiatives are highlighted.

\section{Canada}

\section{CSi Governance Disclosure Conformance Study}

In June 2007 the Canadian Securities Administrators conducted a review of corporate governance disclosure among Canadian publicly traded companies. The study included 100 companies covering all provinces. The study assessed the degree of conformance to the CSA's governance disclosure requirements on topics such as how board members are selected, how the board ensures that members comply with the board's code of conduct, and how compensation for

\footnotetext{
${ }^{25}$ A comparison of market capitalizations between the two countries' biggest stock exchanges demonstrates their size disparity and understandable influence of the US's regulatory systems over Canada's: NYSE market capitalization is US $\$ 25.1$ trillion compared to TSX market capitalization of $\$ 1.7$ trillionInvalid source specified.
}

Corporate Governance Issues Surrounding Executive Compensation and Executive Severance 
directors and officers is decided upon (CSA Staff Notice 58-303 Corporate Governance Disclosure Compliance Review, 2007).

While $70 \%$ to $94 \%$ of respondents answered each question, the regulator found that either practice or reporting was sub-standard (CSA Staff Notice 58-303 Corporate Governance Disclosure Compliance Review, 2007). Twenty-seven percent of companies were required to resubmit their filings to include more comprehensive information (CSA Staff Notice 58-303 Corporate Governance Disclosure Compliance Review, 2007).

This study appears to indicate that Canadian corporate boards may not be conforming to good corporate governance practices intended to ensure that board activities are performed in an objective manner that reduces managerial influence and/or the effects of the agent-principal problem. This failure to comply with regulations can ultimately lead to increased legislative oversight.

\section{New Compensation Disclosure Rules}

On September 18, 2008 the Canadian Securities Administrators issued new rules regarding executive compensation disclosure. The rules became applicable for fiscal years ending in December 2008 and thereafter. In summary, the rules require companies to improve transparency on executive compensation for the company's "named executive officers", including disclosure of all types of compensation including the value of defined benefit and defined contribution pensions and any termination, resignation, retirement or change in control related payments (Medland \& Wright, 2008). Increased disclosure has generally been in the form of increasing use of plain language, and clearer data compilation. 
In addition, a section entitled "compensation analysis and discussion" is now required to explain the compensation components and the business rationale supporting them (Medland \& Wright, 2008) so that investors have insight into "overall stewardship and governance" (Canadian Securities Administrators, 2008).

\section{CSA Public Consultation}

On December 19, 2008 the Canadian Securities Administrators announced it would consult with the public regarding changes to its national policies entitled Corporate Governance Guidelines and Corporate Governance Practices. The CSA is considering replacing the Guidelines and Practices with nine principles. Broadly, these draft principles state that companies should:

- Have a written board mandate, and written position descriptions for each role,

- Have suitable numbers of independent directors on the board and on each committee,

- Ensure that directors are sufficiently qualified to carry out their roles,

- Constantly improve the performance of the board,

- Encourage ethical behavior among board members,

- Understand where conflicts of interest exist and address them appropriately,

- Understand risks and establish a framework for addressing risks and uncertainty,

- Implement compensation practices that align with shareholder interests,

- Understand shareholders opinions and perspectives (Stikeman Elliott, 2009).

Companies will be required to report not only specific information about their board and committee composition, but will also be required to explain to the CSA how the board complies in practice with each of the nine principles (Stikeman Elliott, 2009). This consultation was closed 
on April 20, 2009 and the final document has yet to be released (Canadian Securities Administrators, 2008).

\section{United States}

\section{SEC Statement wegarding Executiva Compensation}

On June 10, 2009 the SEC issued an announcement that, although the SEC's role is not to "set pay scales or cap compensation", it plans to issue new proxy disclosure rules that cover four aspects of executive compensation (U.S. Securities and Exchange Commission, 2009).

The SEC believes that a short-term orientation to incentive plans greatly contributed to the 2008 economic collapse (U.S. Securities and Exchange Commission, 2009). As a result, the first two proposals concern how companies manage risk and their approach to compensation systems (U.S. Securities and Exchange Commission, 2009). Thirdly, the SEC proposes that greater disclosure about the relationships between compensation consultants and firms will provide shareholders with a better understanding of potential conflicts of interest and of the context within which consulting advice has been given (U.S. Securities and Exchange Commission, 2009). Fourth, the SEC is proposing that shareholders be provided with more information about director nominees, including their qualifications and experience to serve on the board and its committees, and how a board determines the best board composition (U.S. Securities and Exchange Commission, 2009).

\section{U.S. Department of Treasury Statement regarding Executive Compensation}

Simultaneous with the issuance of the SEC's statement, U.S. Treasury Secretary Timothy Geithner announced that two sets of federal legislation would be introduced on the topic of executive pay. The first would authorize the SEC to require companies to allow non-binding 
shareholder votes on executive compensation (Statement by Treasury Secretary Tim Geithner on Compensation, 2009). This legislation has been dubbed "Say on Pay" (Statement by Treasury Secretary Tim Geithner on Compensation, 2009). The second seeks to provide compensation committees with the same level of independence, authority and tools (U.S. Department of the Treasury, 2009) that audit committees obtained through the introduction of Sarbanes-Oxley legislation in 2002 (Statement by Treasury Secretary Tim Geithner on Compensation, 2009) so that they are able to develop executive compensation programs that have not been unduly influenced by other members of the board. Using Audit Committee independence guidelines has also been recommended for independent directors in Canadian organizations by global risk management and research organization RiskMetrics Group (RiskMetrics Group, 2008).

These two legislative changes are intended to achieve a number of objectives: effective measurement of performance and appropriate rewards; appropriate time horizon for objective measure of performance results; appropriate risk levels that do not jeopardize the company's viability; re-evaluation and/or elimination of "golden parachutes" and other supplemental payments made upon an executive's retirement, depending on whether these deliver shareholder value; and accountability and transparency (Statement by Treasury Secretary Tim Geithner on Compensation, 2009).

\section{SEC Public Consultation}

The Securities and Exchange Commission engages in public consultation regarding potential new rules and concept releases on the SEC website. In relation to this paper's subject, there is currently one proposed rule under review, which proposes facilitating the nomination of directors 
by shareholders ${ }^{26}$ (U.S. Securities and Exchange Commission, 2009), which would reduce the opportunity for cronyism and the application of managerial power. The SEC believes that shareholders will have a greater ability to hold directors accountable if they are effectively able to nominate directors (U.S. Securities and Exchange Commission, 2009).

The proposal also recommends that shareholders be provided with the opportunity to submit resolutions requesting changes to a company's governing documents (charter, articles of incorporation and bylaws) in some situations (U.S. Securities and Exchange Commission, 2009). Since DGCL permits many aspects of a corporation's processes to be defined in these documents which are subsequently immune from shareholder changes, this proposed change might permit shareholders to make welcome changes to the way corporations are overseen and managed, including how these pertain to executive selection and compensation.

\section{Responses}

Not everyone agrees with the legislative changes being proposed in Canada and the U.S. In Canada, the Institute of Corporate Directors wrote to the Ontario Securities Commission to convey its disagreement with the proposed CSA changes, stating that the changes would not improve corporate governance and would place an undue burden on companies and investors.

In the United States, the Business Roundtable, the previously mentioned group of CEOs of large publicly traded companies, opposes the recommendations and guidelines proposed by the SEC. During the consultation process that took place in 2003, the Business Roundtable indicated that it was not in agreement with permitting shareholders greater freedom to present

\footnotetext{
${ }^{26}$ It appears that shareholders are limited from effectively nominating directors due to the fact that a great many shareholders "attend" the AGM by proxy rather than in person due to the travel cost involved (U.S. Securities and Exchange Commission, 2009).
} 
directors for board positions, and provided the SEC with a 90-page response letter outlining their concerns, most of which pertain to the administrative process followed to implement the changes, the lack of the SEC's authority to enact the changes, and the lack of time provided for the consultation (Business Roundtable, 2003).

\section{Summary}

Recent regulatory activity in Canada and the United States has targeted executive compensation and the severances that are based on it in publicly traded companies and how these companies are overseen and managed.

The main principle that has guided this activity is that the more transparent an issue becomes, the more the issue becomes subject to public scrutiny, which in turn encourages more ethical corporate behaviour. In this case, executive compensation was previously the sole domain of the board; SEC and CSA legislation has required more and more disclosure of the elements of executive compensation in terms that shareholders can understand, thereby generating scrutiny and commentary that encourages boards to ensure that only reasonable executive compensation is provided.

A second underlying principle is that the greater the number of people that consider an issue, the greater the probability that a reasonable solution can be found. The contrast in approaches between the CSA/SEC and corporate boards with respect to public participation is stark. The CSA and the SEC perform public consultations to gather input from all manner of stakeholders to ensure that the best possible solutions are considered and implemented. Some corporate boards, on the other hand, appear to resist input, giving the perception that they prefer to consult only with insiders, but insiders, it has been argued, are subject to influence, making 
free-flowing ideas and discussion difficult, especially as some board members will be subject to these decisions. This has resulted in some sub-optimal solutions being presented and implemented.

The unwillingness of corporate boards to receive shareholder input, even that input which they can subsequently ignore, is evident in these legislative edicts. It is not possible to predict whether greater shareholder involvement might have prevented or lessened the financial collapse in 2008. However, it is unlikely that shareholders would have permitted the level of compensation that failed Lehman Brothers' board authorized to be paid to its CEO, Richard Fuld, (\$484 million over 8 years) (Feiden, 2008) when these funds might have kept the company solvent.

The degree of disclosure and shareholder involvement legislation being introduced by securities regulators in Canada and the U.S. will help to shed more light on board activities with the expected result of creating a greater atmosphere of discussion and better decisions. However, the introduction of ever more stringent regulations and legislation may not ensure that boards meet their fiduciary duties. Boards may focus on meeting the letter of the law but not necessarily its intent and may continue to find ways to circumvent the underlying objectives of new SEC and CSA regulations. 


\section{Recommendations and Conclusion}

This paper has demonstrated that some executive severances are excessive. The problems resulting in these excessive severances can be classified into two categories: compensationspecific and corporate governance related.

\section{Compensation Issues}

Compensation design is the process of determining what level of compensation a position should be provided, what that compensation should comprise and when it is payable. As previously mentioned, CEO compensation can include a base salary, a cash incentive, equity awards, a vehicle allowance, etc. A number of compensation design issues exist in the current board environment, including the payment of severances when none is warranted, excessive stock packages, larger and larger salaries caused by competitive market information and oneupmanship.

The paper identified that the largest component of media reported "severances" was stock/options, although it was revealed that the stock and options were not, in fact, severances, but rather the cumulative stock and options executives had compiled over the term of their sometimes lengthy careers with the firm. This type of reporting is inappropriate as it unfairly skews readers' perceptions of the "severances". However, the review revealed that executives had gained stock and options totaling between $\$ 73$ million and \$252 million. Boards and compensation committees should determine the impact of stock and stock option grants over the course of an executive's career to ensure these are appropriate and not excessive.

The use of 2.99 as a multiplier for determining a maximum severance amount appears reasonable, provided that firms see this as a maximum and not the formula to be used in every 
case of executive termination. As previously mentioned, using this formula to calculate the severance for an executive with six months of service would be inappropriate, but reasonable in the case of an executive with 30 years of service.

One approach that might be used by organizational behaviourists would be to examine the intrinsic and extrinsic rewards of the CEO position in order to realign the role's compensation with the position's accountabilities and responsibilities, and eliminate the use of wages to reward for intrinsic factors (Buckman, 1991). For example, a CEO may be the type of person who enjoys the feeling of importance of being CEO. This is an intrinsic reward that forms part of the benefit of performing the CEO role. Compensation should not be used to attempt to quantify this feeling and convert it into a monetary reward.

The origins of many of these compensation design issues can be traced back to managerial power and cronyism which the introduction of effective corporate governance practices would improve. Based on these points, qualified, competent compensation committees and their external consultants will be able to design optimal executive incentive packages provided they are permitted appropriate independence.

This paper has recognized that a dual level of agents exist in corporations, that is, the director-agent level and the management-agent level, and has focused predominantly on management compensation issues. However, boards are also facing increased pressure in the form of time commitments, demands for higher levels of accounting and compensation expertise and increased liability (Lawler III \& Finegold, 2007). Already this group receives compensation in the form of cash and/or equity stakes in the company. Current director compensation is a fraction of CEO compensation; while CEO compensation is in the millions of dollars, U.S. board 
members earn on average $\$ 69,000$ to $\$ 152,000$ (BDO Seidman, LLP, 2009). Since this group has the authority to set its own compensation (Bebchuk \& Fried, 2006), it is possible that compensation for this group will become the next area of concern for shareholders.

\section{Comorate Governance}

While the design of an executive's employment package, including the composition of compensation during employment, severance, and change in control clauses, is important, it is the structure and functioning of the board of directors that ultimately decides what the employment package will be. Therefore, problems or issues concerning executive compensation are ultimately problems of corporate governance. Effective corporate governance encourages the hiring of qualified directors well-versed in compensation matters for compensation committees, and the hiring of qualified and capable directors for board nominating committees, both areas through which CEOs could create a positive atmosphere for negotiating a favourable employment contract. One survey (mentioned above) had suggested that boards felt that the biggest contributor to high executive compensation was compensation consultants. Since consultants have no actual responsibility in this regard, the board cannot disavow responsibility for compensation issues; the problem rests squarely on the board's shoulders and if consultants are not meeting the board's needs, new consultants should be retained.

The discussion entitled "CEO Shortage" indicated that objective Human Resources practices exist that can help diminish possible procedural flaws in current CEO candidate selection processes. Building on these objective identification and selection processes, Nominating and Governing Committees could, for example, identify and present two or three "equally qualified" candidates to the board, rather than to present only one preferred candidate or a ranked shortlist. The board should intentionally assume an ambivalent mindset to assess the 
suitability of each candidate; each candidate's qualifications should be compared to the job criteria, and no attempt should be made to rank them. In this way, perhaps boards will be able to avoid becoming heavily vested in one candidate and subsequently offering higher and higher compensation in order to secure the preferred individual. Granted, at some point one candidate will be selected for offer presentation, but the objective process, combined with one or more "equally qualified" back-up candidates, may prevent escalating compensation agreements. This type of approach increases the level of procedural justice in CEO selection. Provided that the process (Harris, What's Wrong with Executive Compensation?, 2009)for selecting a CEO was fair, shareholders and other stakeholders can be satisfied that managerial power plays a smaller role in securing and negotiating a final candidate.

Equity ownership and other stock price based executive incentives, although they align executives' interests with those of shareholders, have the inherent problem that not every market movement has been caused by corporate activities. This incentive structure does not reflect a basic compensation tenet: that objective achievement should be solely under the control of the incumbent. In lower echelons of the organization, many Human Resources professionals train managers in the process of setting effective objectives. Organizational objective setting is based on the goal setting work of Locke and Latham (Locke \& Latham, 2002). The ability to achieve the objective through the incumbent's own efforts answers the question "Do you have full control over the resources and achievement of this objective?" If the answer is no, the objective should be changed so that it meets this criterion. If these steps are not taken, once the end of the performance has been reached, managers are faced with a difficult decision on how to handle the unmet objective. Often, a manager's guilt at having failed to correctly define the objective, and 
pressure from the employee, cause the company to pay the incentive amount. The careful setting of objectives avoids this situation.

The same fallout results if boards set CEO objectives that are not effective ${ }^{27}$. The example given at the beginning of the last paragraph concerned CEO share price objectives. A CEO may enact many changes that impact share price. However, the company's stock price can also fall or rise due to situations unrelated to the company's activities. For example, the recent U.S. financial collapse caused stock prices of Canadian banks to fall, although some of them had not participated in sub-prime mortgages. If the CEOs of these Canadian banks had incentives tied to stock price increase, they would have been unfairly impacted by this event.

According to Paul Schneider, Director of Research for the Canadian Coalition for Good Governance, CEOs should not receive the benefits of market fluctuations:

Members ${ }^{28}$ need to see a definite linkage between pay and performance. Performance is a very complex issue as it should have a longer term focus and should be measured using appropriate metrics that are under the control of the executives (i.e. it is hard to argue that a CEO can affect the price of a commodity so the compensation program rewards should not be tied to commodity prices). A true pay for performance regime will pay less in bad years and more in good years and committees must resist the urge to use discretion to increase compensation when performance is lower to keep the CEO happy.

Conversely, we have seen that executives are able to manipulate the company's stock price through false information to ensure incentive payments, as occurred at Computer Associates Inc. Boards should be cognizant of these issues in setting and subsequently paying out executive incentives to ensure they do not pay out in unwarranted situations.

\footnotetext{
${ }^{27}$ To clarify, activity within the firm is deemed dictated by the CEO/president, and therefore meets effective goalsetting criteria, although the achievement may have been attained by someone below the CEO/president.

${ }^{28}$ Institutional shareholders
} 
One possible recommendation to rectify current corporate governance problems is to eliminate one of the two levels of agent. Since the day-to-day running of the corporation is a necessity, the board of directors could be eliminated, resulting in corporate management reporting directly to shareholders. Executive management could determine compensation, and shareholders could approve or reject the proposal by majority vote. However, this structure would present some problems, since it would in effect free management from the closer supervision and "sounding board" that a board provides. Furthermore, the identification and selection of CEO candidates would need to be overseen by someone, which would likely result in the establishment of a committee of shareholders, which would effectively result in what exists today.

Bebchuk \& Fried jokingly suggest that another layer should be introduced; that of "superdirectors" to oversee the directors (Bebchuk \& Fried, 2006). They realize, of course, that this is nonsense and just serves to exacerbate the existing dual-level agency problem.

The solution to this dilemma has not yet been determined, despite a vast range of scholarly and other work. Fuller disclosure in plain language may provide researchers and other thinkers with sufficient information to identify the optimal configuration of CEO, board and shareholder interaction and decision making.

Exhibit 5 in the section entitled Shareholder Discontent and Activism demonstrated the growth of shareholder resolutions over the course of ten years. The number of resolutions presented by shareholders in 1998 is minimal, leading one to believe that perhaps Bainbridge accurately identified that shareholders prefer director primacy. Perhaps shareholders do not wish to be involved in matters normally handled by the board; they appear to be generally content to 
let directors and managers run the business. However, when they feel that a degree of unfairness has infiltrated the process, they become outraged, more active and vociferous. Executive compensation has become one of these issues.

With respect to the relationship between board members and the shareholders whose interests they are intended to represent, the impression given by boards is that they welcome shareholders' investments but expect them to be a voiceless, non-participating financier of the business, similar to the role of a silent partner. Unless a company is run by the founding family this perspective is not understandable in corporate boards, since the corporation belongs to no one (Pruijm), although it may be understandable that they resent the intrusion of participants they feel know little about the company's business and doubt can contribute meaningfully.

It also appears that boards have a closer relationship with management (or inside) directors than they do with shareholders. After all, they meet with management directors every month. In contrast they see shareholders once a year, and then only the shareholders that choose to or are able to attend the meeting. Communication between boards and shareholders are formally defined, except in a few cases where boards, such as McDonald's and Home Depot (Deane, 2009), have held meetings for the sole purpose of facilitating board/shareholder relations. Furthermore, antiquated methods of communication are used; communication is either by postal mail or by face-to-face meeting.

Open discussion between these two groups should be encouraged. For example, a website or blog could be established through which shareholders could provide feedback and ideas to directors. This would eliminate the formality of current communication processes between the two, and would increase the frequency of communication from annual to much more frequently. 
Alternatively, live web-chats could be coordinated between the two groups. One possible drawback of these approaches is that shareholders are diverse and many resulting in board members being inundated with many conflicting opinions. Boards would have to establish someone (or a committee) responsible for gathering and determining the majority direction of the feedback. This is not insurmountable and could result in drawing the two groups together, especially where boards put in the effort to actually listen to the concerns on shareholders' minds. The track record of directors listening to the interests and concerns of shareholders is, however, dismal, considering the scores of director-rejected shareholder resolutions found on SEDAR and EDGAR databases, especially those in which shareholders have raised the same issue annually for years. It would appear that any truly effective means of bringing the two groups together requires mandating, as is currently underway through the SEC in the U.S. and CSA in Canada.

This paper has also discussed that the right of shareholders to appoint directors of their choosing is a myth (Bebchuk \& Fried, 2006), unless a particular shareholder or group of likeminded shareholders have a controlling interest over a firm. Most shareholders who wish to participate in board matters are merely permitted the opportunity to vote on board candidates that have been put forward by existing board members, since it is the responsibility of the Nominating and Governing Committee to identify candidates to serve on the board. This view is supported by Bebchuk and Fried's research in the area of corporate governance (Bebchuk \& Fried, 2006).

The SEC's planned legislation permitting shareholders to place a limited number of directors on boards is further evidence of the lack of shareholder control over a company's board. It is understandable how this type of structure can occur; shareholders are many and 
diverse; shareholders may not be qualified to identify qualified board candidates; it would be difficult for shareholders to find possible board candidates, especially as many shareholders do not participate; even if shareholders suggested board candidates, it is not certain that sufficient votes would result in the candidate's successful placement on the board. However, the U.S.'s proposed legislation to permit shareholders to submit candidates for board nomination will encourage a tighter connection between board members and shareholders, and perhaps cause boards to be more open to shareholder input and feedback. In "Pay without Performance: The Unfulfilled Promise of Executive Compensation" Bebchuk and Fried state that permitting shareholders to identify and select the board should be encouraged and feel that greater director dependence on shareholders would correct many of the issues surrounding corporate governance today (Bebchuk \& Fried, 2006).

\section{Conchusion}

The issue of executive severances finds its origins in executive compensation that is negotiated between executives and boards, who are advised by compensation committees and their consultants. Executives are capable influencers of issues that impact them, and executive compensation is one of those issues. Greed may also be playing a significant role, as executives attempt to out-do each other in a game of corporate one-upmanship.

This paper found that boards are performing their fiduciary duty, which is to the corporation, not to shareholders; that CEOs appear to be able to exercise managerial power in influencing their employment contract (which covers compensation during their employment, as well as severance and change in control clauses); that the agency problem continues to exist and present challenges; that CEO shortages can be overcome by broadening the pool from which candidates are selected; that there is no scarcity of compensation data, and that, in fact, extensive 
compensation data may be driving CEO compensation (and therefore severances) to new heights; that shareholders are indeed disempowered due to the terms of incorporation legislation and a company's incorporation documents (bylaws, charter and articles of incorporation); and that there appears to be a struggle between management and shareholders over who should receive the profits generated by the company.

The governance structure of today's Canadian and U.S. corporations is impacted by issues that may be minimized through ethical and responsible leadership. When corporations and their boards fail to demonstrate fairness in decision making, shareholders become outraged and actively pursue changes to the method in which corporations are overseen and managed. Increased disclosure covering the terms of an executive's employment contract and shareholder advisory votes may ensure appropriate executive compensation levels and provide shareholders will sufficient information to determine whether they wish to invest in a company that includes severance and change in control clauses that may have a future impact on shareholder wealth. Legislators seek to encourage appropriate corporate behavior through the introduction of new laws that force corporations to disclose compensation practices so that investors can decide whether they wish to continue to invest in companies, dependent on their ethical and responsible leadership of the firm, thereby addressing some aspects of informational asymmetry.

The use of Human Resources expertise resident within the firm has been entirely ignored in the setting and oversight of executive compensation. Human Resources practices provide objective structures to identify candidates for roles and maintain reasonable wages, which could be brought to bear on executive compensation and severance arrangements. For example, perhaps the introduction of an executive salary grade would contain CEO pay within a determined range. In addition, the benefits of involving Human Resources might include that a Corporate Governance Issues Surrounding Executive Compensation and Executive Severance Andrea W. Zanetti 
greater pool of qualified CEO candidates is identified, which might lessen the need to provide ever higher compensation, leading to an overall reduction in CEO compensation in the market. The introduction of these types of objective practices roots out areas of procedural injustice within organizations and ensures a greater sense of fairness for all stakeholders.

This solution, however, is not without its challenges. Human Resources personnel would not be immune to managerial influence. Again, a Human Resources professional addressing the executive's compensation and severance arrangements would be subject to a conflict of interest as $\mathrm{s} /$ he recognizes the sensitivity of the issue, and attempts to avoid offending or riling the CEO by proposing a lesser package than expected, while trying not to lose his or her job over the issue. Human Resources professionals could seek support from the board; however, it has already been established that this group struggles with the same challenge. As a result, this approach may result in subjecting one more person to the risky business of determining executive compensation and severance arrangements.

Perhaps the time of the big pay cheques in publicly traded corporations is over. As Kaplan points out, CEOs appear to be moving to private equity firms to avoid public scrutiny of board activity and executive compensation (Kaplan, 2007). If this is the case, then it may take some time for a new generation of executives to arise who realize that corporations cannot provide compensation in the range previously publicized in the media. Perhaps those who pursue that single-minded objective will be drawn to private equity firms and others, more driven by intrinsic rewards, will pursue publicly traded companies. 


\section{References}

About RiskMetrics Group. (n.d.). Retrieved July 8, 2009, from RiskMetrics:

http://www.riskmetrics.com/our_company

AFL-CIO's CEO Pay Database. (n.d.). CEO Pay Database. Retrieved May 28, 2009, from AFLCIO: AFL-CIO's CEO Pay Database

Aird \& Berlis LLP. (2008, June). BCE Decided by Supreme Court of Canada: A Debt Really Is Just A Debt. Retrieved July 29, 2009, from Aird \& Berlis:

http://www.airdberlis.com/Templates/Newsletters/newsletterFiles/90/BCE\%20Decision \%20-\%20June\%202008.pdf

Allison, M. (2008, October 1). WaMu's Fishman would refuse \$11M in severance pay. Retrieved May 25, 2009, from The Seattle Times:

http://seattletimes.nwsource.com/html/businesstechnology/2008220153_webfishman02.h tml

American Compensation Association (WorldatWork). (1998, September 28). Certification Seminar C6 Elements of Executive Compensation. Scottsdale, Arizona, U.S.A.

Anderson, S., Cavanagh, J., Collins, C., Pizzigati, S., \& Lapham, M. (2008, August 25). Executive Excess 2008: How Average Taxpayers Subsidize Runaway Pay 15th Annual CEO Compensation Survey. Retrieved June 3, 2009, from Institute for Policy Studies: http://www.ipsdc.org/reports/executive_excess_2008_how_average_taxpayers_subsidize_runaway_pay

Astron Solutions LLC. (2007). Compensation 101 - Why Should Organizations Utilize Pay Ranges? Retrieved July 31, 2009, from WorldatWork: http://www.worldatwork.org/waw/adimLink?id=21441\&nonav=yes

Avery, S., \& McFarland, J. (2009, April 1). Golden parachutes: how much is too much? Retrieved April 28, 2009, from Globe and Mail: http://ago.mobile.globeandmail.com/generated/archive/RTGAM/html/20090401/wrparac hutes02.html 
Bainbridge, S. (2006). Director Primacy and Shareholder Disempowerment. Harvard Law Review, 119, 1735-1758.

Bainbridge, S. (2005, September). Unocal at 20: Director Primacy in Corporate Takeovers.

Retrieved June 8, 2009, from Social Science Research Network:

$\mathrm{http}: / /$ ssrn.com/abstract $=796224$

Bank Failures in 2008. (n.d.). Retrieved May 14, 2009, from cnbc.com:

http://www.cnbc.com/id/26673834/26720522?slide=14

BCE. (2009, March 11). BCE Notice of 2009 Annual General Shareholder Meeting and Proxy Circular. Retrieved May 26, 2009, from BCE:

http://www.bce.ca/data/documents/BCE_Proxy_en_2009.pdf

BDO Seidman, LLP. (2009, January 21). Financial Services Board Member Compensation lowest across all industries according to BDO Seidman, LLP study. Retrieved July 14 , 2009, from BDO Seidman, LLP: http://www.bdo.com/news/pr/988

Bebchuk, L., \& Fried, J. (2006). Pay Without Performance: The Unfulfilled Promise of Executive Compensation. Cambridge: First Harvard University Press.

Bisson, D. (2009, March). The Trouble with Options ... And What You Can Do About It. Workspan, pp. 26-30.

Booth, R. (2008 (Forthcoming), April). Five Decaded of Corporation Law - From Conglomeration to Equity Compensation. Retrieved May 16, 2009, from Social Science Research Network: http://papers.ssrn.com/sol3/papers.cfm?abstract_id=1109003\&rec=1\&srcabs=1112703

Brick, I., Palmon, O., \& Wald, J. (2009, April 1). CEO Compensation, Director Compensation and Firm Performance: Evidence of Cronyism. Retrieved May 27, 2009, from SSRN Working Paper Series: ABI/INFORM Global database. (Document ID: 1450919781).

Buckman, E. (1991). Motivating and Retaining People. Executive Excellence, 8 (11), 9. 
Business Roundtable. (2007, January). Executive Compensation: Principles and Commentary. Retrieved June 23, 2009, from Business Roundtable:

http://www.businessroundtable.org/sites/default/files/ExecutiveCompensationPrinciples.p df

Business Roundtable. (2003, December 22). Letter to ABA Taskforce on Director Elections. Retrieved July 9, 2009, from Business Roundtable: http://www.businessroundtable.org/sites/default/files/1079.pdf

Canadian Coalition for Good Governance. (2009, June). 2009 Executive Compensation Principles. Retrieved June 22, 2009, from Canadian Coalition for Good Governance: http://www.ccgg.ca/media/files/guidelines-and-policies/compensation/CCGG-ECPFINAL-June2.pdf

Canadian Coalition for Good Governance. (2005, February 16). Statement of Principles Regarding Member Activism. Retrieved June 22, 2009, from Canadian Coalition for Good Governance: http://www.ccgg.ca/media/files/guidelines-andpolicies/Statement $\% 20 \mathrm{of} \% 20$ PrinciplesMember\%20Activism\%20\%28Rev.\%20Version\%20-\%20Feb\%2016\%202005\%29.pdf

Canadian Securities Administrators. (2008, September 19). Canadian Securities Regulators Implement Improvements to Executive Compensation Disclosure. Retrieved July 8, 2009, from Canadian Securities Administrators: http://www.securitiesadministrators.ca/aboutcsa.aspx?id=377

Canadian Securities Administrators. (2008, December 18). Canadian Securities Regulators Seek Comments On Revised Corporate Governance And Audit Committee Regimes. Retrieved July 8, 2009, from Canadian Securities Administrators: http://www.securitiesadministrators.ca/aboutcsa.aspx?id=749

Carter, M. E., \& Zamora, V. (2009, January). Shareholder Remuneration Votes and CEO Compensation Design . Retrieved June 12, 2009, from Social Science Research Network: http://papers.ssrn.com/sol3/papers.cfm?abstract_id=1004061 
Catalyst 2008 Census of the Fortune 500 Reveals Women Gained Little Ground Advancing to Business Leadership Positions . (2008, December 10). Retrieved July 30, 2009, from Catalyst: http://www.catalyst.org/press-release/141/catalyst-2008-census-of-the-fortune500-reveals-women-gained-little-ground-advancing-to-business-leadership-positions

Cohen, B., \& Fitzgerald, B. (2002). The Pension Puzzle. Etobicoke: John Wiley \& Sons Canada Limited.

Cohen, K. (2006, September). The Pulse of the Profession: 2006-07 Salary Budget. Workspan , pp. 23-26.

Companies With More Women Board Directors Experience Higher Financial Performance, According to Latest Catalyst Bottom Line Report. (2007, October 1). Retrieved July 30, 2009, from Catalyst: http://www.catalyst.org/press-release/73/companies-with-morewomen-board-directors-experience-higher-financial-performance-according-to-latestcatalyst-bottom-line-report

Corporate Governance. (n.d.). Retrieved June 23, 2009, from Business Roundtable: http://www.businessroundtable.org/initiatives/leadership/governance

Corporate Leadership. (n.d.). Retrieved June 23, 2009, from Business Roundtable: http://www.businessroundtable.org/initiatives/leadership

Corrado, C., Jordan, B., \& Yuce, A. (2006). Fundamentals of Investments Valuation and Management, Canadian Edition. Toronto: McGraw-Hill Ryerson.

Corrado, C., Jordan, B., \& Yuce, A. (2006). Fundamentals of Investments Valuation and Management, Canadian Edition. Toronto: McGraw-Hill Ryerson.

Cozzolino, P., \& Snyder, M. (2008). Good Times, Bad Times: How Personal Disadvantage Moderates the Relationship Between SocialDominance and Efforts to Win. Personality and Social Psychology Bulletin (34), 1420 - 1433. 
CSA Staff Notice 58-303 Corporate Governance Disclosure Compliance Review. (2007, June 29). Retrieved July 6, 2009, from Institute of Corporate Directors:

http://www.icd.ca/Docs/58_303.pdf

CSA's SEDAR database. (n.d.). Management Information Circular. Retrieved May 27, 2009, from SEDAR: SEDAR

Culpepper. (2008). Salary Range Structure Practices and Increase Budgets for 2008 and 2009.

Retrieved July 31, 2009, from WorldatWork:

http://www.worldatwork.org/waw/adimLink?id=31737

Deane, S. (2009). Board-Shareholder Dialogue: Why They're Talking. The Corporate Goverance Advisor , 15 (3), 16-24.

Delaware Division of Corporations. (n.d.). Retrieved July 9, 2009, from State of Delaware: http://corp.delaware.gov/

Department of Justice Canada. (2009, March 29). Canada Business Corporations Act. Retrieved May 15, 2009, from Department of Justice Canada:

http://laws.justice.gc.ca/en/showdoc/cs/C-44/bo-ga:1_X//en\#anchorbo-ga:1_X

Department of Justice Canada. (2009, March 29). Canada Business Corporations Act, Part X, Directors and Officers. Retrieved May 16, 2009, from Department of Justice Canada: http://laws.justice.gc.ca/en/showdoc/cs/C-44/bo-ga:1_X//en\#anchorbo-ga:I_X

Department of Justice Canada. (2009, March 29). Purposes of Act. Retrieved May 16, 2009, from Department of Justice Canada: http://laws.justice.gc.ca/en/showdoc/cs/C-44/boga:I_I-gb:s_4//en\#anchorbo-ga:I_I-gb:s_4

Division of Research of Legislative Council of the General Assembly. (2009, April 30).

Delaware General Corporate Law, Subchapter I, Formation. Retrieved May 16, 2009, from State of Delaware: http://delcode.delaware.gov/title8/c001/index.shtml\#P-1_0

Division of Research of Legislative Council of the General Assembly. (2009, April 30).

Delaware General Corporate Law, Subchapter IV. Directors and Officers. Retrieved 
May 16, 2009, from State of Delaware:

http://delcode.delaware.gov/title8/c001/sc04/index.shtml

Division of Research of Legislative Council of the General Assembly. (2009, May 14).

Delaware General Corporation Law, Subchapter VII, Meetings, Elections, Voting and Notice. Retrieved May 21, 2009, from State of Delaware:

http://delcode.delaware.gov/title8/c001/index.shtml

Djankov, S., La Porta, R., de Silanes, F. L., \& Shleifer, A. (2005, December). The Law and Economics of Self-Dealing. Retrieved June 15, 2009, from Social Science Research Network: http://papers.ssrn.com/sol3/papers.cfm?abstract_id=864645

Dow Jones \& Company, Inc. (1996, April 11). Different Fortunes. Retrieved May 28, 2009, from Wall Street Journal Online: http://online.wsj.com/public/resources/MoneyInvesting/reference/b-fort.html

Feiden, D. (2008, November 5). Disgraced Lehmann Brothers CEO Richard Fuld calling it quits. Retrieved July 7, 2009, from New York Daily News: http://www.nydailynews.com/money/2008/11/05/2008-1105_disgraced_lehmann_brothers_ceo_richard_f.html

Forelle, C. (2004, May 26). Computer Associates Offers to Settle; Proposal Includes Payment Of $\$ 10$ Million, Vow to Use Stricter Accounting Method. Retrieved June 15, 2009, from ABI/Inform Global: ABI/INFORM Global database. (Document ID: 642321411)

Fortune 500. (2009). Retrieved May 25, 2009, from CNN Money: http://money.cnn.com/magazines/fortune/fortune500/2009/

Fortune Magazine. (2008, July 21). Fortune's Global 500. Retrieved June 20, 2009, from CNN Money: http://money.cnn.com/magazines/fortune/global500/2008/full_list/

Gomstyn, A. (2008, September 23). AIG CEO Rejects \$22 million Parachute; Will Others Follow? Retrieved May 25, 2009, from ABC News: http://abcnews.go.com/Business/MarketTalk/story?id=5861458\&page=1 
Good Goverance Guidelines for Principled Executive Compensation. (2006, June). Retrieved June 4, 209, from Canadian Coalition for Good Governance:

http://www.ccgg.ca/media/files/guidelines-and-

policies/guidelines/CCGG\%20Principled\%20Executive\%20Compensation\%20(FINAL\% 20Version\%20-\%20June\%202006).pdf

Government of Canada. (n.d.). Financial Services. Retrieved May 16, 2009, from Invest in Canada: http://investincanada.gc.ca/eng/industry-sectors/financialservices.aspx

Greenwald, J. (2009, January - February). Getting Back on the Diversity Track. Retrieved June 9, 2009, from Corporate Board Member:

http://www.boardmember.com/MagazineArticle_Details.aspx?id=2944\&page=1

Guidera, J. (2002, May 16). Probe of Computer Associates Widens as Subpoenas Are Issued. Retrieved June 15, 2009, from Wall Street Journal (Eastern Edition): ABI/INFORM Global database. (Document ID: 119847573)

Gulati, G. M., Klein, W. A., \& Zolt, E. M. (2000). Connected contracts. Retrieved June 18, 2009, from ProQuest: ABI/Inform Global database. (Document ID: 53556980).

Hagerty, J. (2008, January 28). Countrywide CEO Shamed into Forfeiting \$37.5 Million Severance Pay. Retrieved May 25, 2009, from The Huffington Post: http://www.huffingtonpost.com/2008/01/28/countrywide-ceo-shamed-in_n_83579.html

Harris, J. (2009). What's Wrong with Executive Compensation? Journal of Business Ethics (85), 147-156.

Harris, J., \& Bromiley, P. (2007). Incentives to cheat: the influence of executive compensation and firm performance on financial misrepresentation. Organizational Science, 18 (3), $350-368$.

Hassell, J., Hanson, J., \& Meyer, T. (2008, December). Employing A Different Standard Essential in Canada. Retrieved July 31, 2009, from Osler: http://www.osler.com/resources.aspx?id=11339 
Herbst, M. (2006, December 22). The Golden Parachute Club of 2006. Retrieved May 15, 2009, from BusinessWeek:

http://www.businessweek.com/bwdaily/dnflash/content/dec2006/db20061222_672252.ht $\mathrm{m}$

Home Depot CEO Nardelli quits. (2007, January 3). Retrieved May 29, 2009, from MSNBC: http://www.msnbc.msn.com/id/16451112//

Home Depot. (2007, April 4). Home Depot 2006 Definitive Proxy Statement. Retrieved May 26, 2009, from SEC:

http://www.sec.gov/Archives/edgar/data/354950/000104746907002827/a2176842zdefl 4 a.htm

Home Improvement Can Get Very Messy. (2007, January 22). Retrieved May 25, 2009, from Newsweek: http://www.newsweek.com/id/70082

Hood, D. (2009, May 5). Gluttons at the gate. Retrieved May 28, 2009, from Macleans: http://www2macleans.ca/2009/05/05/gluttons-at-the-gate/print/

Industry Canada. (2009, January 9). Chapter 1 - Why should I incorporate? Retrieved May 16, 2009, from Industry Canada: http://www.ic.gc.ca/eic/site/cd-dgc.nsf/eng/cs01357.html

Industry Canada. (2005, June 8). Oppression Remedy Guidelines. Retrieved July 6, 2009, from Industry Canada: http://www.ic.gc.ca/eic/site/cd-dgc.nsf/eng/cs02883.html

Institutional investor definition. (n.d.). Retrieved June 22, 2009, from InvestorWords: http://www.investorwords.com/2504/institutional_investor.html

Jensen, M., \& Meckling, W. (1976). Theory of the firm: managerial behaviour, agency costs and ownership structure. Journal of Financial Economics (4), 305 - 360.

Kamlet Reichert Legal Updates. (2005, October). Retrieved June 8, 2009, from Kamlet Reichert: http://www.kamletlaw.com/NewsPage.aspx?id=LegalUpdates\&article=LegalUpdates 000 55850-4

Kaplan, S. N. (2007). Are CEOs Overpaid? WorldatWork Journal (Third Quarter), 22-37. 
Kaufer, J., \& Radell, J. (2009). Standards of Review; Officer Fiduciary Duties; and Shareholder Ratification. Busines Law Today , 18 (5), 57, 64.

Kay, I. P., \& Seelig, S. L. (2007, August). A Reasonable Approach to Severance and Change in Control Payments. Retrieved May 15, 2009, from Watson Wyatt Worldwide: http://www.watsonwyatt.com/us/pubs/Insider/showarticle.asp?ArticleID=17660

Keay, A. (2008). Ascertaining the Corporate Objective: An Entity Maximisation and Sustainability Model. Modern Law Review , 71 (5), 663-698.

Kirbyson, G., \& Lett, D. (2007, April). Burned investors fire back. Retrieved June 22, 2009, from Canadian Business: ABI/Inform Global database (Document ID: 1276981851)

Konrad, R. (2007, March 29). Take-two shareholders oust board members. Retrieved June 10, 2009, from USA Today: http://www.usatoday.com/money/industries/technology/200703-29-take-two-shareholders_N.htm

Lawler III, E. E., \& Finegold, D. (2007). CEO Compensation: What Board Members Think. WorldatWork Journal (Third Quarter), 38-44.

Lee, I. B. (2005). Peoples Department Stores v. Wise and "Best Interests of the Corporation". The Canadian Business Law Journal[Agincourt] , 41 (2,3), 212-222.

Locke, E., \& Latham, G. (2002). Building a Practically Useful Theory of Goal Setting and Task Motivation: A 35-Year Odyssey. American Psychologist , 57 (9), 705-717.

Lublin, J. (1989, December 11). Grappling With the Expatriate Issue --- Companies Try To Cut Subsidies For Employees. Retrieved June 23, 2009, from Wall Street Journal (Eastern Edition): ABI/INFORM Global database. (Document ID: 27559675)

Mackenzie, H. (2007, December). The Great CEO Pay Race: Over before it Begins. Retrieved June 4, 2009, from Canadian Centre for Policy Alternatives: http://www.policyalternatives.ca/documents/National_Office_Pubs/2008/The_Great_CE O_Pay_Race.pdf 
Manulife Financial Corporation. (2008, April 22). Retrieved June 9, 2009, from ISS Governance Services, Canadian Proxy Advisory Services:

https://ga.issproxy.com/repository/Documents/2008/1/1/6/M/396479AA.htm

Maremont, M. (2005, January 31). No Razor Here: Gillette Chief to Get A Giant Payday.

Retrieved May 29, 2009, from Wall Street Journal:

http://w4.stern.nyu.edu/emplibrary/YermarckWSJ013105.pdf

Matsumura, E., \& Shin, Y. (2005). Corporate Governance Reform and CEO Compensation:

Intended and Unintended Consequences. Journal of Business Ethics (62), 101-113.

McQueen, R. (1999). Special Issue: 100 Years of Salomon's Case: Life without Salomon.

Retrieved July 29, 209, from Pandora Australia's Web Archive:

http://pandora.nla.gov.au/nph-arch/2000/Z2000-Oct-

26/http://law.anu.edu.au/publications/flr/Vol27no2/mcqueen.htm

Medland, C., \& Wright, C. (2008, September 30). New Rules for Executive Compensation Disclosure. Retrieved July 7, 2009, from Torys:

http://www.torys.com/Publications/Documents/Publication\%20PDFs/CCM2008-24.pdf

Mercer. (2007, December 20). Executive Remuneration Perspective \#68: Change in control:

New data supports best practices. Retrieved July 10, 2009, from Mercer:

http://www.mercer.com/referencecontent.htm?idContent $=1291210$

Minken \& Associates. (n.d.). Concepts in Employment Law. Retrieved June 12, 2009, from Minken \& Associates: http://www.employmentlawissues.com/concepts.php?aid=34

Moran, N., \& Yap, R. (2007, November 2). O'Neal Ranks No. 5 on Payout List, Group Says: Table. Retrieved May 25, 2009, from Bloomberg:

http://www.bloomberg.com/apps/news?pid=20601109\&refer=home\&sid=aPxzn5U8zNB o

Morgenson, G. (2005, December 25). Severance Pay Doesn't Go Better With Coke. Retrieved June 11, 2009, from The New York Times: 
http://query.nytimes.com/gst/fullpage.html?res=9C02E3DB1530F936A15751C1A9639C $8 \mathrm{~B} 63 \& \mathrm{sec}=\&$ spon $=$

Moyer, L. (2007, October 31). Super-size that Severance! Retrieved May 25, 2009, from Forbes: http://www.forbes.com/2007/10/30/merrill-severance-compensation-biz-wallcx_lm_1031failure.html

Nardelli's "Severance". (2007, January 5). Retrieved May 27, 2009, from The Wall Street Journal: http://online.wsj.com/article/SB116796470509467824.html

National Association of Corporate Directors. (2009). Key Agreed Principles to Strengthen Corporate Governance for U.S. Publicly Traded Companies. Retrieved July 7, 2009, from National Association of Corporate Directors: https://secure.nacdonline.org/StaticContent/StaticPages/DM/NACDKeyAgreedPrinciples .pdf

Nordick, D. (2006, October). M\&A Update. Retrieved June 8, 2009, from Stikeman Elliott LLP: http://www.stikeman.com/en/pdf/JudgementRule_Disney_Nordick_Oct06.pdf

Nowak, P. (2009, January 19). Palm's Pre smartphone blends best of iPhone, BlackBerry.

Retrieved June 23, 2009, from CBCNews:

http://www.cbc.ca/money/story/2009/01/12/tech-ces-roundup.html

NYSE. (n.d.). Listed Company Manual, 303A.00 Corporate Governance Standards. Retrieved May 15, 2009, from NYSE Euronext:

http://nysemanual.nyse.com/LCMTools/PlatformViewer.asp?selectednode $=$ chp $\% 5 F 1 \% 5$ $\mathrm{F} 4 \&$ manual $=\% 2 \mathrm{Flcm} \% 2 \mathrm{Fsections} \% 2 \mathrm{Flcm} \% 2 \mathrm{Dsections} \% 2 \mathrm{~F}$

NYSE. (2004, November 3). NYSE 303A.00 Corporate Governance Standards. Retrieved May 15, 2009, from NYSE Euronext:

http://nysemanual.nyse.com/LCMTools/PlatformViewer.asp?searched=1\&selectednode= chp $\% 5$ F $1 \% 5 F 4 \% 5 F 3 \% 5 F 1 \&$ CiRestriction=303A\&manual=\%2Flcm $\% 2 F s e c t i o n s \% 2 F l c$ $\mathrm{m} \% 2 \mathrm{Dsections} \% 2 \mathrm{~F}$ 
Oakley, J. G. (2000). Gender-based Barriers to Senior Management Positions: Understanding the Scarcity of Female CEOs. Journal of Business Ethics , 27 (4), 321-334.

Oil: Exxon Chairman's $\$ 400$ Million Parachute. (2005, April 14). Retrieved May 29, 2009, from ABC News: http://abcnews.go.com/GMA/story?id=1841989\&page=1

Olmos, D. (2009, June 2). Amylin Shareholders oust Chairman, elect 2 Dissidents. Retrieved June 10, 2009, from Bloomberg:

http://www.bloomberg.com/apps/news?pid=20601202\&sid=apTZmDJ0sUkE

Onaran, Y., \& Scinta, C. (2008, September 15). Lehman makes largest bankruptcy filing in history. Retrieved May 14, 2009, from Financial Post: http://www.financialpost.com/story.html?id=790965

Ontario Securities Commission. (2004, March 26). Category 5 - Ongoing Requirements for Issuers and Insiders Multilateral Instrument 52-110 Audit Committees. Retrieved May 17, 2009, from Ontario Securities Commission:

http://osc.gov.on.ca/Regulation/Rulemaking/Current/Part5/rule_20040326_52-110-auditcomm.pdf

Ontario Securities Commission. (2004, March 26). Category 5 - Ongoing Requirements for Issuers and Insiders, Companion Policy 52-110CP to Multilateral Instrument 52-110 Audit Committees. Retrieved May 17, 2009, from Ontario Securities Commission: http://osc.gov.on.ca/Regulation/Rulemaking/Current/Part5/rule_20040326_52-110-auditcomm.pdf

Ontario Securities Commission. (2004, October 29). National Policy 58-201 Corporate Goverance Guidelines. Retrieved May 16, 2009, from Ontario Securities Commission: http://www.osc.gov.on.ca/Regulation/Rulemaking/Current/Part5/rule_20041029_58201_corp-gov-guidelines.jsp

Osler, Hoskin \& Harcourt LLP. (2009, March). Corporate Goverance in Canada: A Guide to the Responsibilities of Corporate Directors in Canada. Retrieved May 16, 2009, from Osler.com: 
http://www.osler.com/uploadedFiles/Resources/Publications/8115_CorpGovCanada2009. pdf

Paranzino, G. (n.d.). How Do I Get A Better Severance Package? A Lawyer's View. Retrieved June 20, 2009, from Severance-Package.com: http://www.severance-package.com/

Pooley, E. (2005, August 15). How To Get A Boardroom Seat. Retrieved June 9, 2009, from Canadian Business Online: http://www.canadianbusiness.com/managing/article.jsp?content=20050815_70004_7000 4

Pruijm, R. (n.d.). Who Owns The Corporation. Retrieved July 9, 2009, from SlideShare: http://www.slideshare.net/ruudpruijm/who-owns-the-corporation

Public Law 107-204 - July 30, 2002. (2002, July 30). Retrieved May 22, 2009, from frwebgate.access.gpo.gov: http://frwebgate.access.gpo.gov/cgibin/getdoc.cgi?dbname=107_cong_public_laws\&docid=f:publ204.107.pdf

RiskMetrics Group. (2008, December 31). 2009 Proxy Voting Guidelines. Retrieved July 8, 2009, from RiskMetrics Group: http://www.riskmetrics.com/sites/default/files/2009CanadianTSXGuidelines.pdf

Robbins, S. (1993). Organizational Behaviour: Concepts, Controversies, and Applications, Sixth Edition. Engelwood Cliffs: Prentice Hall.

Roberts, B. (2000, January). Executive pay snafu. Retrieved June 15, 2009, from Electronic Business: ABI/INFORM Global database. (Document ID: 47901185)

Roberts, B. (2004, January). Shareholders take aim at executive pay. Retrieved June 19, 2009, from Electronic Business: ABI/INFORM Global database. (Document ID: 525721961)

Ross, B., \& Gomstyn, A. (2008, October 6). Lehman Brothers Boss Defends $\$ 484$ million in Salary, Bonus. Retrieved June 20, 2009, from ABC News: http://abcnews.go.com/Blotter/story?id=5965360\&page=1 
U.S. Securities and Exchange Commission. (2008, September 26). The Laws that Govern the Securities Industry. Retrieved May 22, 2009, from U.S. Securities and Exchange Commission: http://www.sec.gov/about/laws.shtml

Useem, J. (2003, April 28). Have They No Shame? Their performance stank last year, yet most CEOs got paid more than ever. Here's how they're getting away with it. Retrieved June 11, 2009, from $\mathrm{CNN}$ :

http://money.cnn.com/magazines/fortune/fortune_archive/2003/04/28/341716/index.htm

Webster's New World Law Dictionary. (2006). Shareholder legal definition. Retrieved May 19, 2009, from yourdictionary.com: http://www.yourdictionary.com/law/shareholder

World's largest stock exchanges. (2007, June 23). Retrieved May 19, 2009, from Reuters: http://www.reuters.com/article/businessNews/idUSL2224181520070623

Cappiello, Stefano. (2006). Lucian Bebchuk and Jesse M. Fried, Pay without Performance: The Unfulfilled Promise of Executive Compensation (Cambridge, MA, and London, UK, Harvard University Press 2004) xii +278 pp., ISBN 0-674-01665-3. European Business Organization Law Review, 7(3), 753-763. Retrieved May 27, 2009, from ABI/INFORM Global database. (Document ID: 1396111141). 